\title{
Characterization of Fusarium Isolates from Asparagus Fields in Southwestern Ontario and Influence of Soil Organic Amendments on Fusarium Crown and Root Rot
}

\author{
Ana Borrego-Benjumea, María J. Basallote-Ureba, José M. Melero-Vara, and Pervaiz A. Abbasi
}

First and fourth authors: Southern Crop Protection and Food Research Centre, Agriculture and Agri-Food Canada, 1391 Sandford Street, London, Ontario, Canada N5V 4T3; first and third authors: Instituto de Agricultura Sostenible, CSIC, Alameda del Obispo S/N, P.O. Box 4084, 14080 Córdoba, Spain; and second author: IFAPA Centro Las Torres-Tomejil, Apdo. 41200, Alcalá del Río, Sevilla, Spain.

Current address of fourth author: Atlantic Food and Horticulture Research Centre, Agriculture and Agri-Food Canada, 32 Main Steet, Kentville, Nova Scotia, Canada B4N1J5.

Accepted for publication 7 November 2013.

\begin{abstract}
Borrego-Benjumea, A., Basallote-Ureba, M. J., Melero-Vara, J. M., and Abbasi, P. A. 2014. Characterization of Fusarium isolates from asparagus fields in southwestern Ontario and influence of soil organic amendments on Fusarium crown and root rot. Phytopathology 104:403-415.

Fusarium crown and root rot (FCRR) of asparagus has a complex etiology with several soilborne Fusarium spp. as causal agents. Ninetythree Fusarium isolates, obtained from plant and soil samples collected from commercial asparagus fields in southwestern Ontario with a history of FCRR, were identified as Fusarium oxysporum (65.5\%), F. proliferatum (18.3\%), F. solani (6.4\%), F. acuminatum (6.4\%), and F. redolens (3.2\%) based on morphological or cultural characteristics and polymerase chain reaction (PCR) analysis with species-specific primers. The intersimple-sequence repeat PCR analysis of the field isolates revealed considerable variability among the isolates belonging to different Fusarium spp. In the in vitro pathogenicity screening tests, $50 \%$ of the field isolates were pathogenic to asparagus, and $22 \%$ of the isolates caused the most severe symptoms on asparagus. The management of FCRR with soil
\end{abstract}

ABSTRACT

Asparagus (Asparagus officinalis L.) is a low-input and highvalue perennial crop able to give profitable yields for 10 to 15 years after 3 years of crop establishment. Canada has a cultivated area of 1,559 ha and a production of 6,599 t/year (26) and $>70 \%$ of asparagus is produced in Ontario. Fusarium crown and root rot (FCRR) is probably one of the most important diseases of asparagus worldwide $(8,20,47)$. FCRR has been associated with asparagus decline, accounting for the reduction in quantity and size of the spears produced, and the death of plants (38). Furthermore, early decline or replant disease are denominations of the damage caused to asparagus crops when old asparagus fields are replanted with asparagus; yields are slowly reduced in 5 to 10 years on the old crop, and plants are unable to establish productive plantings (28).

The FCRR has a complex etiology, with the occurrence of several soilborne Fusarium spp. as causal agents associated with asparagus roots (17). Fusarium oxysporum Schltdl., F. proliferatum (Matsush.) Nirenberg, and, to a lesser extent, F. culmorum (W. G. Sm.) Sacc. are the main species involved in asparagus plantations in North America and recognized as causal agents of several symptoms, such as dwarf asparagus, wilt and root rot,

Corresponding author: P. A. Abbasi; E-mail address: Pervaiz.Abbasi@agr.gc.ca

http://dx.doi.org/10.1094/PHYTO-08-13-0231-R

(C) 2014 The American Phytopathological Society organic amendments of pelleted poultry manure (PPM), olive residue compost, and fish emulsion was evaluated in a greenhouse using three asparagus cultivars of different susceptibility in soils infested with two of the pathogenic isolates (F. oxysporum Fo-1.5 and $F$. solani $F_{s}-1.12$ ). Lower FCRR symptom severity and higher plant weights were observed for most treatments on 'Jersey Giant' and 'Grande' but not on 'Mary Washington'. On all three cultivars, $1 \%$ PPM consistently reduced FCRR severity by 42 to $96 \%$ and increased plant weights by 77 to $152 \%$ compared with the Fusarium control treatment. Populations of Fusarium and total bacteria were enumerated after $1,3,7$, and 14 days of soil amendment. In amended soils, the population of Fusarium spp. gradually decreased while the population of total culturable bacteria increased. These results indicate that soil organic amendments, especially PPM, can decrease disease severity and promote plant growth, possibly by decreasing pathogen population and enhancing bacterial activity in the soil.

Additional keywords: molecular analysis. seedling blight, foot rot, and stem and crown rot (17). In Canada, asparagus crops also suffer from severe a FCRR problem $(29,30)$ that frequently compromises the production profitability but there is little information available regarding the distribution and prevalence of Fusarium spp. associated with FCRR. The diversity of Fusarium populations in asparagus fields has been reported within the Quebec growing areas in eastern Canada $(54,59,60)$.

With the development of modern molecular techniques, rapid and objective identification of fungi at species or even at intraspecific level is now possible (42). Polymerase chain reaction (PCR)-based techniques have been used to investigate the genetic diversity among isolates of Fusarium spp. of many crops. Methods such as PCR-denaturing gradient gel electrophoresis (58), PCR analysis with species-specific primers (39), or restriction fragment length polymorphism analysis (52) have been used to examine Fusarium spp. diversity in asparagus crop. Analysis with inter-simple sequence repeats (ISSR), a new kind of molecular marker of polymorphic DNA by a single primer, is also utilized to explore the intra- and interspecific differences of a wide variety of Fusarium spp. (6,51).

Although attempts have been made to control FCRR through cultural, biological, and fungicidal approaches $(9,18,19,24,32,45)$, the management of FCRR can be challenging, particularly in the fields where disease has been established due to the long-term nature of this crop. The choice of land with no prior history of FCRR is usually the first measure to avoid an FCRR problem. 
Fungicide drench application of benomyl and fludioxonil to asparagus seedlings in the greenhouse were reported to increase asparagus root weight and decrease the disease under low levels of $F$. oxysporum and $F$. proliferatum (45). In contrast, application of these fungicides via drip irrigation in fields with a history of asparagus production resulted in a lack of significant differences among treated and untreated plots (16). Thus, the chemical control of this disease is not consistent and, additionally, it may have risks to humans and negative effects on the environment (27), therefore being incompatible for sustainable agriculture.

Alternatively, organic amendments can provide control of several soilborne plant diseases $(4,11,33,35,43)$. Fusarium diseases have been managed with soil organic amendments in many horticultural crops, including asparagus, tomato, carnation, cucumber, strawberry, and spinach $(9,13,21,23,25,31,37)$. In asparagus, soil amendments with fresh broccoli or grass subsequently covered with air-tight plastic significantly reduced the populations of $F$. oxysporum f. sp. asparagi after 15 weeks of incubation (9). Similarly, animal manures, such as raw or pelleted poultry manure, and composts derived from agroindustrial wastes, combined with the incubation of soil at different temperatures and periods, showed a reduction in the density of viable inocula of $F$. oxysporum f. sp. asparagi, $F$. proliferatum, and F. solani (12; A. Borrego-Benjumea, unpublished data). However, despite the importance of FCRR in North America, there is little information available regarding the management of this asparagus disease in Canada with soil organic amendments.

The objectives of this study were to identify and characterize the Fusarium spp. associated with FCRR of asparagus in southwestern Ontario using DNA-based PCR methods and ISSR-PCR analysis, and to investigate the effects of organic amendments such as animal manures, composts, and fish emulsions from the agricultural and fish-processing industry on populations of pathogens and soil bacteria, and on disease development, in order to assess its management.

\section{MATERIALS AND METHODS}

Isolation of Fusarium spp. from asparagus ecosystems. Eleven commercial asparagus fields in southwestern Ontario, Canada, were surveyed in 2011 and 2012 to collect plant and soil samples for this study. From each field, 5 to 10 plants were arbitrarily taken. The asparagus plants were dug from the soil with a spade. Plant roots were shaken to collect soil from the rhizosphere for isolation purposes. Plants from each field were pooled and placed in plastic bags and brought to the laboratory. They were air dried, placed in paper bags, stored at $5^{\circ} \mathrm{C}$, and used within a week for making isolations. The rhizosphere soil samples from the plants of each field were pooled and mixed to make one soil sample per field. The air-dried rhizosphere soil was placed in plastic bags, stored at $5^{\circ} \mathrm{C}$, and used within a week for making isolations.

Fusarium isolations from asparagus plant tissues were made from stems (at the base near the intersection), crowns (or rhizomes), and roots (including storage and secondary roots) as described previously $(15,22,54)$, with some modifications. Because the root surface is greater than the crown surface in the root system of asparagus plants, the percentages of the different parts assayed were $16 \%$ basal stem pieces, $34 \%$ crown pieces, and $50 \%$ root pieces. The plant tissues were thoroughly washed under running tap water and cut into $4-$ to $5-\mathrm{cm}$ pieces, surface disinfested by dipping in $1 \%$ sodium hypochlorite solution $(20 \%$ household bleach) for $1 \mathrm{~min}$, and air dried for $10 \mathrm{~min}$ under sterile conditions. Then, each piece was cut into small, $0.5-\mathrm{cm}$ pieces with a sterile scalpel and placed on the surface of potato-dextroseagar (PDA) medium, supplemented with antibiotics (streptomycin sulfate at $100 \mathrm{mg} / \mathrm{liter}$ and neomycin sulfate at $12 \mathrm{mg} / \mathrm{liter}$ ) (Sigma-Aldrich, St. Louis, MO).
Isolations of Fusarium from rhizosphere soil were performed by the plate-culturing method as described previously $(22,54)$, with some modifications. The soil sample from each field was thoroughly mixed and a 10-g subsample was taken for isolation on Fusarium-selective agar mediums $(14,53)$ containing agar, peptone, streptomycin sulfate, neomycin sulfate, and pentachloronitrobenzene (PPA) or myclobutanil (MBA). Each subsample was diluted in $0.1 \%$ water agar and dilutions $\left(10^{-2}\right.$ to $\left.10^{-5}\right)$ were spread on the surface of PPA and MBA plates. The plates were incubated in the dark at $24^{\circ} \mathrm{C}$ for 7 to 10 days.

Culturing and identifying Fusarium spp. The individual Fusarium-like colonies from the plates were transferred to PDA plates and incubated in the dark at $24^{\circ} \mathrm{C}$ for 10 days for growth and sporulation. Microscopic observation of fungal structures was also performed to characterize the isolates to Fusarium genus. In total, 93 Fusarium cultures with different colony morphologies were recovered from PDA plates and further purified. The monosporic cultures were subcultured on PDA and used for further characterization. A first approach for the identification of the isolates was based on morphological characteristics on PDA medium. Cultural characteristics such as colony color and morphology were assessed by visual examination, and morphology of macro- and microconidia was recorded from cultures grown on PDA by microscopic examination $(5,34)$. Later, this primary identification was confirmed or corrected by molecular characterization with PCR analysis with species-specific primers and ISSR-PCR analysis.

Molecular assays. In order to extract DNA for PCR analysis, Fusarium isolates were grown on PDA plates for 7 days and three to four 8-mm-diameter plugs with fungal mycelium were aseptically transferred to $50-\mathrm{ml}$ aliquots of sterilized liquid potato dextrose broth in 150-ml Erlenmeyer flasks. Cultures were grown at room temperature $\left(22^{\circ} \mathrm{C}\right)$ for 6 days under low agitation $(110$ rpm). Fusarium mycelial mats were freeze dried and ground in liquid nitrogen with a mortar and pestle. Total genomic DNA of fungal isolates was isolated from dried mycelium $(\approx 100 \mathrm{mg})$ using the E.Z.N.A. Fungal DNA Miniprep Kit (Omega Bio-Tek, Norcross, GA), according to the manufacturer's protocol. DNA was recovered and dissolved in elution buffer and stored at $-20^{\circ} \mathrm{C}$ until PCR amplification. DNA quality was assessed by gel electrophoresis. Concentrations of DNA were determined by spectrophotometer NanoDrop, ND-1000 (NanoDrop Technologies, Wilmington, DE).

The colonies of Fusarium spp. obtained above were identified based on PCR analysis with species-specific primer pairs developed by Yergeau et al. (58) for all Fusarium spp., Williams et al. (56) for F. acuminatum, Mulè et al. (39) for $F$. oxysporum and $F$. proliferatum, and Bogale et al. (10) for detection of F. redolens. The $F$. solani-specific primer pair FSOL1/2 were designed on the basis of the sequence of Fusarium field isolate $F s-1.12$ with Primer-BLAST (46). Previously, the nuclear ribosomal internal transcribed spacer (ITS) region of the isolate $F s-1.12$ was amplified with universal primers ITS4 and ITS5 (55), using as cycling parameters $10 \mathrm{~min}$ at $95^{\circ} \mathrm{C}$; followed by 40 cycles of $30 \mathrm{~s}$ at $94^{\circ} \mathrm{C}, 30 \mathrm{~s}$ at $56^{\circ} \mathrm{C}$, and $2 \mathrm{~min}$ at $72^{\circ} \mathrm{C}$; and a final extension for $10 \mathrm{~min}$ at $72^{\circ} \mathrm{C}$. The resulting products were purified and analyzed on the 3730 Genetic Analyzer (Applied Biosystems, Forest City, CA) at the London Regional Genomics Centre DNA Sequencing Facility. The sequences of the species-specific primers are given in Table 1. Three known asparagus-pathogenic isolates $-F$. oxysporum f. sp. asparagi (Foa 4$)$, F. proliferatum, $(F p 9)$, and $F$. solani ( Fs2) (15)—were used as positive controls, and sterile, double-distilled $\mathrm{H}_{2} \mathrm{O}$ instead of DNA was included as negative control in each experiment. The reaction mixtures were prepared in a total volume of $25 \mu \mathrm{l}$ with a final concentration of $2.5 \mu \mathrm{l}$ of $10 \times$ PCR buffer, $0.8 \mathrm{mg} / \mathrm{ml}$ of bovine serum albumen (BSA), $2.5 \mathrm{mM} \mathrm{MgCl}_{2}$, and $0.2 \mathrm{mM}$ each dNTP. For each reaction, $1.25 \mathrm{U}$ of Taq polymerase (Invitrogen, Carlsbad, CA), 
$0.4 \mu \mathrm{M}$ each primer, and $\approx 25 \mathrm{ng}$ of fungal template DNA were used. PCR conditions for the FSOL1/2 primer pair were an initial denaturation at $94^{\circ} \mathrm{C}$ for $3 \mathrm{~min}$; followed by 35 cycles of denaturation at $94^{\circ} \mathrm{C}$ for $30 \mathrm{~s}$, annealing at $65^{\circ} \mathrm{C}$ for $50 \mathrm{~s}$, and extension at $72^{\circ} \mathrm{C}$ for $1 \mathrm{~min}$; a final extension at $72^{\circ} \mathrm{C}$ for $5 \mathrm{~min}$; followed by cooling at $4^{\circ} \mathrm{C}$ until recovery of the samples. For the other primer pairs, PCR conditions were same as described by the authors mentioned above. Amplified products were separated by $1.5 \%$ agarose gel electrophoresis in $1 \times$ Tris-acetate-EDTA buffer and visualized after staining with GelRed $(10 \mu \mathrm{g} / \mathrm{ml})$.

All 93 Fusarium isolates from asparagus fields were further characterized with ISSR-PCR to investigate the degree of genetic variability among and within different Fusarium spp. Three known asparagus isolates of Fusarium (Foa4, $F p 9$, and $F s 2$ ) were also included for comparisons and as positive controls. DNA from these isolates was extracted as described above. Eighteen individual primers, based on the production of distinct and reproducible polymorphic banding patterns (51), were used for PCR assays: (AAG) $)_{6},(\mathrm{AC})_{8} \mathrm{~T},(\mathrm{ACA})_{5},(\mathrm{AG})_{8} \mathrm{TA},(\mathrm{AG})_{8} \mathrm{TC}$, $(\mathrm{CAA})_{5},(\mathrm{CCA})_{5},(\mathrm{CTC})_{4},(\mathrm{GA})_{6} \mathrm{GG},(\mathrm{GA})_{8} \mathrm{C},(\mathrm{GA})_{8} \mathrm{~T},(\mathrm{GACA})_{4}$, $(\mathrm{GAG})_{4} \mathrm{GC},(\mathrm{GT})_{6} \mathrm{CC},(\mathrm{GTC})_{6},(\mathrm{GTG})_{5},(\mathrm{AG})_{8} \mathrm{~T}$, and M13. PCR was performed in a total volume of $20 \mu$ l containing $2 \mu \mathrm{l}$ of $10 \times$ PCR buffer, BSA at $0.6 \mathrm{mg} / \mathrm{ml}, 2 \mathrm{mM}$ of $\mathrm{MgCl}_{2}, 0.4 \mu \mathrm{M}$ primer, $10 \mathrm{mM}$ dNTPs mix, $1 \mathrm{U}$ of Taq polymerase (Invitrogen), and $25 \mathrm{ng}$ of template DNA. Amplification was performed as follows: $5 \mathrm{~min}$ at $94^{\circ} \mathrm{C} ; 1 \mathrm{~min}$ at $94^{\circ} \mathrm{C}, 1.5 \mathrm{~min}$ at $50^{\circ} \mathrm{C}$, and $2 \mathrm{~min}$ at $72^{\circ} \mathrm{C}$ for 40 cycles; $7 \mathrm{~min}$ at $72^{\circ} \mathrm{C}$; followed by cooling at $4^{\circ} \mathrm{C}$. Amplified products were separated by $0.8 \%$ agarose gel electrophoresis in $0.5 \times$ Tris-borate-EDTA buffer and visualized after staining with GelRed $\left(10 \mu \mathrm{g} \mathrm{ml}^{-1}\right)$ under UV light, and images were acquired by Gel Doc 2000 System (Bio-Rad, Hercules, CA). A commercial gel documentation system (Quantity One 4.2.1; BioRad) was used as support for the scoring of bands as presence $(=1)$ or absence $(=0)$.

Pathogenicity tests. In vitro experiments were carried out to assess the pathogenicity of 77 isolates selected from the 93 Fusarium isolates obtained above from commercial asparagus fields and identified by molecular analysis. The in vitro pathogenicity of Fusarium isolates in asparagus seedlings was determined as described previously $(15,48)$, with some modifications. Asparagus seed of 'Jersey Giant', 'Mary Washington', and 'Grande' (tolerant, susceptible, and moderately tolerant to Fusarium spp., respectively) were surface disinfested by im- mersion for $3 \mathrm{~min}$ in $20 \%$ household bleach supplemented with $0.05 \%$ Tween 20 and rinsed three times with distilled $\mathrm{H}_{2} \mathrm{O}$, air dried under sterile conditions, and placed on the surface of water agar $(0.6 \%)$ medium. The plates were incubated in the dark at $28^{\circ} \mathrm{C}$ for 7 to 8 days for emergence. Individual plantlets were transferred aseptically to test tubes containing $15 \mathrm{ml}$ of Murashige and Skoog basal salt mixture media with Minimal Organics (MP Biomedicals Inc., Santa Ana, CA). The tubes were loosely capped to allow air exchange and incubated for 2 weeks in a growth cabinet $\left(16 \mathrm{~h}\right.$ of fluorescent light at $23^{\circ} \mathrm{C}$ and $8 \mathrm{~h}$ of darkness at $18^{\circ} \mathrm{C}$ ), until inoculation.

Fusarium isolates were grown on PDA plates for 10 days. The spore suspension used as inoculum was obtained after filtering it through four layers of sterile cheesecloth. The spore concentration was determined using a hemacytometer and adjusted to $1 \times 10^{7}$ conidia/ml. To inoculate the plants, $1 \mathrm{ml}$ of the appropriate spore suspension was deposited next to the roots. Sterile water was added to control plantlets. Plants were incubated for 3 weeks as above. The assay included three replications (plantlets) for each of the 77 isolates tested. At the end of the assay, severity of the symptoms was assessed on a percentage scale of the root system affected on a 1 to 5 scale (15), where $1=1$ to $20,2=21$ to $40,3=$ 41 to $60,4=61$ to 80 , and $5=81$ to $100 \%$ of the root system affected, including crowns and roots. Those isolates that produced lesions on $\geq 20 \%$ of the root system were considered to be pathogenic on asparagus (22).

Soil amendments and microbial assays. Three separate greenhouse experiments were conducted, each with a different asparagus cultivar, to evaluate the effects of various soil treatments on FCRR development on asparagus, on plant growth, on soil populations of Fusarium spp. and culturable bacteria, and on soil $\mathrm{pH}$. These greenhouse experiments were repeated at least twice.

The natural soil used in the three greenhouse experiments was sandy soil ( $85 \%$ sand, $7 \%$ silt, $8 \%$ clay, and $3.6 \%$ organic matter, $\mathrm{pH}$ 6.9) from a field location in Thamesville, Ontario, Canada. This field had been previously under asparagus crop 'Guelph Millennium' for several years. Several soil samples ( $n=25$ to 30) were arbitrarily collected from the top layer of soil to a depth of up to $20 \mathrm{~cm}$. The soil samples (total of $300 \mathrm{~kg}$ ) were mixed into one large composite sample and air dried by spreading on a bench for $48 \mathrm{~h}$ or until soil was in workable condition $(\approx 10 \%$ moisture). Soil subsamples were randomly taken from the large sample to

TABLE 1. Oligonucleotide sequences of species-specific primers

\begin{tabular}{|c|c|c|c|c|}
\hline Primer name & Species specificity & PCR $(b p)^{\mathrm{z}}$ & Primer sequence $\left(5^{\prime}-3^{\prime}\right)$ & Reference \\
\hline Alfie1-GC & Fusarium spp. & 450 & $\begin{array}{l}\text { CGCCCGCCGCGCGCGGCGGGCGGGGCGGGGGCACGGG } \\
\text { GGGTCGTCATCGGCCACGTCGACTC }\end{array}$ & 58 \\
\hline Alfie2 & & & CCTTACCGAGCTCRGCGGCTTC & \\
\hline CLOX1 & F. oxysporum & 534 & CAGCAAAGCATCAGACCACTATAACTC & 39 \\
\hline CLOX2 & & & CTTGTCAGTAACTGGACGTTGGTACT & \\
\hline CLPRO1 & F. proliferatum & 526 & TGCATCAGACCACTCAAATCCT & 39 \\
\hline Red-R & & & CAATGATGATTGTGATGAGAC & \\
\hline FSOL1 & F. solani & 398 & GCTCTCCAGTTGCGAGGTGT & This study \\
\hline FSOL2 & & & TTGCTTCGGCGGGAACAGAC & \\
\hline
\end{tabular}

${ }^{\mathrm{z}}$ Polymerase chain reaction (PCR) product.

TABLE 2. Chemical analyses of organic material used in this study

\begin{tabular}{lccccc}
\hline Organic material & Nitrogen $(\%)$ & Phosphorus $(\%)$ & Potassium $(\%)$ & pH & $\begin{array}{c}\text { Electrical conductivity } \\
(\mathrm{mS} / \mathrm{cm})\end{array}$ \\
\hline Pelleted poultry manure & 4.0 & 1.0 & 2.0 & 6.3 & 11.0 \\
Olive residue compost & 1.5 & 0.7 & 2.0 & 8.7 & $3.2-3.5$ \\
Fish emulsion & 5.0 & 1.5 & 1.8 & $2.4-2.8$ & $19.0-20.5$ \\
\hline
\end{tabular}


determine the density of Fusarium population by the plate culturing method. Each 10-g soil sample was shaken with $90 \mathrm{ml}$ of $0.1 \%$ sterile water agar on a rotary shaker at $100 \mathrm{rpm}$ for $10 \mathrm{~min}$, and the suspension was then serially diluted by placing $1 \mathrm{ml}$ in $9 \mathrm{ml}$ of saline water $(\mathrm{NaCl}$ at $8.5 \mathrm{~g} /$ liter $)$ in tubes, and $1 \mathrm{ml}$ from each of $10^{-2}$ to $10^{-5}$ dilutions was plated onto PPA medium in petri dishes. The density of Fusarium spp. was expressed as the number of colony-forming units (CFU) per gram of soil. The large soil sample was kept in plastic bags for up to 2 weeks after air drying and stored at $5^{\circ} \mathrm{C}$.

Three organic amendments from the agricultural and fishprocessing industry used in this study included a pelleted poultry manure (PPM; Envirem Technologies Inc., NB, Canada), an olive residue compost (ORC; Department of Agriculture and Fisheries, Andalucía, Spain), and a fish emulsion (FE) prepared from whole menhaden fish (Brevoortia patronus Goode and B. tyrannus Latrobe) (Omega Protein, Houston, TX). A nutrient analysis of these amendments is given in Table 2.

Based on the results of in vitro pathogenicity assessment, two pathogenic Fusarium isolates, Fo-1.5 (F. oxysporum) and Fs-1.12 ( $F$. solani), were selected for the greenhouse experiments. The inocula of these isolates were separately grown on sterilized millet seed in 1-liter flasks containing $50 \mathrm{~g}$ of millet seed and 100 $\mathrm{ml}$ of $\mathrm{H}_{2} \mathrm{O}$ as described previously (18), with some minor modifications. The contents of the flasks were autoclaved for $1 \mathrm{~h}$ on two consecutive days. The flasks were then kept at room temperature in a laminar flow hood to cool down before infestation with 10 5-mm-diameter PDA plugs obtained from the outer margins of actively growing colonies of each isolate. Inoculated flasks were incubated at room temperature for 14 days and hand shaken daily for $15 \mathrm{~s}$. The colonized seed from the flasks was air dried for $24 \mathrm{~h}$ in a laminar flow hood under sterile conditions. The dried, colonized seed was ground in a mill for $30 \mathrm{~s}$ at 25,000 rpm to achieve 1- to 2-mm particle size. Fusarium populations of ground inoculum were enumerated by the plate culturing method as described above, and expressed as the number of CFU per gram of inoculum. Soil was bagged according to treatments and infested with the ground millet seed inocula of Fusarium isolates $F o-1.5$ or $F s-1.12$ separately. The infested soil was incubated at $24^{\circ} \mathrm{C}$ for $24 \mathrm{~h}$ in the dark prior to adding the corresponding soil treatments.

The first greenhouse experiment was conducted with Jersey Giant and Fusarium isolates $F o-1.5$ and $F s-1.12$. For each treatment, an aliquot of $2.5 \mathrm{~kg}$ of soil from the large soil sample was infested with the millet seed inoculum of $\mathrm{Fo}-1.5(4 \mathrm{~g} / \mathrm{kg}$ of soil at $\left.9 \times 10^{6} \mathrm{CFU} / \mathrm{g}\right)$ or $F s-1.12\left(6 \mathrm{~g} / \mathrm{kg}\right.$ of soil at $7 \times 10^{7}$ $\mathrm{CFU} / \mathrm{g}$ ), separately, both by mixing in plastic bags. This was enough soil to fill five replicate 10 -cm-diameter plastic pots per treatment. The infested soil from bags was incubated for $24 \mathrm{~h}$ at $24^{\circ} \mathrm{C}$ in the dark before amending with the following treatments: benomyl ( $0.5 \mathrm{~g} /$ liter of soil) as chemical control, PPM (0.5 and $1 \% \mathrm{~m} / \mathrm{m}$ (weight/weight) soil, ORC (3 and $6 \% \mathrm{~m} / \mathrm{m}$ soil), and FE $(0.5 \% \mathrm{~m} / \mathrm{m}$ soil $)$. The pathogen-noninfested and -infested soils served as negative and Fusarium controls, respectively. The amended soil was incubated for 14 days at $24^{\circ} \mathrm{C}$ in the dark prior to planting asparagus seedlings. The treated soils were also sampled at $0,1,3,7$, and 14 days after amendment for determination of population of Fusarium spp. and culturable bacteria, and for soil $\mathrm{pH}$.

In the second greenhouse experiment, Mary Washington asparagus was used. The millet seed inoculum $(3 \mathrm{~g} / \mathrm{kg}$ soil $)$ of either isolate Fo-1.5 $\left(6 \times 10^{7} \mathrm{CFU} / \mathrm{g}\right)$ or Fs-1.12 $\left(1 \times 10^{7} \mathrm{CFU} / \mathrm{g}\right)$ was mixed with $3.8 \mathrm{~kg}$ of soil (from the large composite soil sample) per treatment by mixing in plastic bags. The soil from each bag was enough to fill five replicate 12.5 -cm-diameter plastic pots per treatment. The infested soil from bags was incubated for $24 \mathrm{~h}$ at $24^{\circ} \mathrm{C}$ in the dark before amending with the soil treatments as in the first experiment. The amended soil was incubated for 14 days at $24^{\circ} \mathrm{C}$ in the dark prior to planting. The amended soils were also sampled at $0,1,3,7$, and 14 days after amendment for determination of populations of Fusarium spp. and culturable bacteria, and for soil $\mathrm{pH}$.

The third greenhouse experiment was conducted with Grande and Fusarium isolate $F s-1.12$. For each treatment, $2.5 \mathrm{~kg}$ of soil from the large composite soil sample was infested with the millet seed inoculum $\left(16 \mathrm{~g} / \mathrm{kg}\right.$ of soil at $\left.1 \times 10^{7} \mathrm{CFU} / \mathrm{g}\right)$ by mixing in plastic bags. This was enough soil to fill five replicate $10-\mathrm{cm}-$ diameter plastic pots per treatment. The pathogen-noninfested and -infested soils served as negative and Fusarium controls, respectively. The infested soil from bags was incubated for $24 \mathrm{~h}$ at $24^{\circ} \mathrm{C}$ in the dark before amending with the soil treatments as indicated for experiments 1 and 2, except that ORC was applied at 1 and $3 \% \mathrm{~m} / \mathrm{m}$ soil and $\mathrm{FE}$ at 0.1 and $0.5 \% \mathrm{~m} / \mathrm{m}$ soil. The treated soil was incubated for 10 days at $24^{\circ} \mathrm{C}$ in the dark before planting asparagus seedlings. Differently in this experiment, the amended soils were sampled at $0,3,7$, and 10 days after amendment for determination of population of Fusarium spp. and culturable bacteria, and for soil $\mathrm{pH}$.

Populations of total Fusarium spp. (Fo-1.5, Fs-1.12, and other Fusarium spp. present in natural soil) and culturable bacteria were enumerated to determine the effect of the different treatments on soil microflora by the plate-culturing method as described above, using soil dilutions plated onto semiselective media (bacteria: tryptic-soy-broth-based agar medium; Fusarium spp.: PPA medium), and expressed as the number of CFU per gram of soil. Plates were incubated at $24^{\circ} \mathrm{C}$ for 2 days for bacteria and 4 days for Fusarium spp. Three replicate plates were used for each dilution. For enumeration of Fusarium spp., $1 \mathrm{ml}$ from each of $10^{-2}$ to $10^{-5}$ dilutions was plated and, for bacteria, $1 \mathrm{ml}$ from each of $10^{-5}$ to $10^{-7}$ dilutions.

To determine the soil $\mathrm{pH}$, soil subsamples ( $8 \mathrm{~g}$ ) from each treatment were placed in polyethylene stomacher bags and $40 \mathrm{ml}$ of distilled water was added to each of them. The bags were shaken for $15 \mathrm{~min}$ at $200 \mathrm{rpm}$. The $\mathrm{pH}$ of the soil-water mixture was determined as described previously (49).

To evaluate the development of FCRR disease, Jersey Giant, Mary Washington, and Grande asparagus, of different susceptibility to Fusarium spp., were assessed. Asparagus seed of these cultivars were surface disinfested as described above, transferred to water agar medium $(0.6 \%)$, and kept in the dark at $28^{\circ} \mathrm{C}$ for 7 to 8 days. Once roots began to emerge, seedlings were transferred to trays with sterile sand and placed for 2 weeks in a growth chamber with daily cycles of $16 \mathrm{~h}$ of light at $24^{\circ} \mathrm{C}$ and $8 \mathrm{~h}$ of darkness at $19^{\circ} \mathrm{C}$. The amended soil from each bag was mixed again and transferred to five pots. One seedling each of Jersey Giant and Grande and two seedlings of Mary Washington were transplanted into each corresponding pot and maintained in a greenhouse for 12 weeks at 22 to $24^{\circ} \mathrm{C}$ under a combination of daylight and supplemental lighting (photoperiod $=16 \mathrm{~h}$ of light; light intensity $=225 \mu \mathrm{E} \mathrm{m}^{-2} \mathrm{~s}^{-1}$ ) in a randomized completed block design. Pots were watered daily as required. At the end of each experiment, asparagus plants were removed from the pots and their root systems were rinsed in tap water. The severity of symptoms was assessed by the percentage scale of the stem system affected on a 1 to 5 scale (15), where $1=1$ to $20,2=21$ to $40,3=41$ to $60,4=61$ to 80 , and $5=81$ to $100 \%$ of the aerial part (stems) showing chlorosis, necrosis, or wilt (15) and of the root system affected, including crowns and roots, as described above. Fresh weights were recorded for each treatment after rating the plants and dry weights were taken after the plants had dried for $48 \mathrm{~h}$ in an oven at $70^{\circ} \mathrm{C}$.

Statistical analyses. The bands generated by ISSR primers from each gel were scored as present $(=1)$ versus absent $(=0)$ and the resulting data matrix was analyzed by Minitab statistical software (version 16.0; Minitab Inc., State College, PA). The genetic similarity matrix was subjected to cluster analysis with 
complete linkage and the Euclidean distance option of the software to generate a dendrogram. All experiments were repeated at least twice and yielded similar results. Separate analyses of each experiment showed homogeneous variance of the experimental error between replications. Data of symptom severity were angle transformed and analyzed using analysis of variance (ANOVA) $(P \leq 0.01)$. ANOVA of Fusarium population and culturable bacteria were performed on previous log CFU transformation of data. The means were compared using the least significant difference test $(P=0.01)$ for pathogenicity experiments and $(P=$ $0.05)$ for the soil organic amendments experiments. All analyses were performed with Statistical analyses of data supported by Statistix 9.0 software (Analytical Software, Tallahassee, FL).

\section{RESULTS}

Culturing and identifying Fusarium spp. Of the 93 field isolates of Fusarium spp. collected from 11 asparagus fields in southwestern Ontario, 77 were obtained from asparagus plants (7\% from basal stems, $29 \%$ from crowns, and 64\% from roots), and 16 from rhizosphere soil. Of those isolates, 61 were identified as $F$. oxysporum (65.5\%), 17 as $F$. proliferatum (18.3\%), 6 as $F$. solani (6.4\%), 6 as $F$. acuminatum $(6.4 \%)$, and 3 as $F$. redolens (3.2\%), based on cultural characteristics and morphological criteria. F. oxysporum was present in all fields and was the dominant species, followed by $F$. proliferatum and $F$. solani $(73$ and $45 \%$ isolation frequency, respectively). F. acuminatum was isolated from three fields and $F$. redolens was only found in one field (Table 3). Of the 77 isolates obtained from asparagus plants, $66 \%$ belong to $F$. oxysporum, $15 \%$ to $F$. proliferatum, $8 \%$ to $F$. acuminatum, $8 \%$ to $F$. solani, and $3 \%$ to $F$. redolens. Of the 16 isolates from rhizosphere soil, $63 \%$ belong to $F$. oxysporum, $31 \%$ to $F$. proliferatum, and $6 \%$ to $F$. redolens.

Molecular assays. The species-specific PCR assays confirmed the identity of most of these field isolates of Fusarium spp. associated with asparagus by amplifying bands of the expected size for each species (Fig. 1). The primer set Alfie1-GC/2 amplified a single 450-bp fragment from all field isolates, confirming their identity as Fusarium spp. (Fig. 1A). The primer sets CLOX1/2 and CLPRO1/2 produced the expected 534- and 526-bp fragments specific for $F$. oxysporum and $F$. proliferatum isolates, respectively (Fig. 1B and $1 \mathrm{C}$ ), and FAC F/R produced the expected 600-bp fragments specific for $F$. acuminatum (Fig. 1D). The primer set FSOL1/2 produced the 398-bp fragment specific for F. solani isolates (Fig. 1E) but a very faint band was also amplified in 10 isolates of $F$. oxysporum, whereas Red-F/R produced a 386-bp fragment specific for F. redolens isolates (Fig. 1F).

The ISSR-PCR analysis of 93 Fusarium field isolates using 18 ISSR primers revealed a considerable intraspecific and interspecific variability among isolates of Fusarium spp. Clear and reproducible DNA fragments were scored consistently in repeated amplifications from all isolates. The amplified fragments ranged in size from 225 to $3,000 \mathrm{bp}$, and the number of ISSR bands obtained with each primer varied from 18 to 33 . A PCR amplification pattern generated by using the ISSR primer (AAG) ${ }_{6}$ is shown in Figure 2. The presence or absence of these bands was analyzed with complete linkage and Euclidean distance. The analysis of ISSR data clustered the isolates belonging to the same species into the same groups (Fig. 3). The dendrogram indicated that $F$. oxysporum isolates formed two clusters. The genetic similarity found in each one of these clusters was 71 and $65 \%$. The genetic similarity for $F$. solani and $F$. redolens was $58 \%$. The similarity of $F$. proliferatum and $F$. acuminatum was 51.3 and $50 \%$, respectively (Fig. 3).

Pathogenicity tests. The common symptoms developed on the root system were brown to reddish-brown necrotic lesions of variable length. In all three cultivars, a wide range in virulence was observed between the Fusarium field isolates. The average root rot severity of isolates showed a wide range (2 to $94 \%$ ) with the three asparagus cultivars tested and, depending on the cultivar, 47 to $51 \%$ of the isolates resulted in root severity values $\geq 20 \%$ of the root system (Fig. 4). Only $22 \%$ of the field isolates, including five $F$. oxysporum isolates $(F o-1.3, F o-1.4, F o-1.5, F o-6.1$, and $F o-11.4)$, four $F$. solani isolates $(F s-1.12, F s-4.5, F s-6.3$, and $F s-7.3)$, and five $F$. acuminatum isolates ( $F a-3.6, F a-10.1, F a-10.2$, $F a-10.4$, and $F a-10.6$ ), caused severity values $\geq 50 \%$ in the three cultivars (Fig. 4A to $\mathrm{C}$ ).

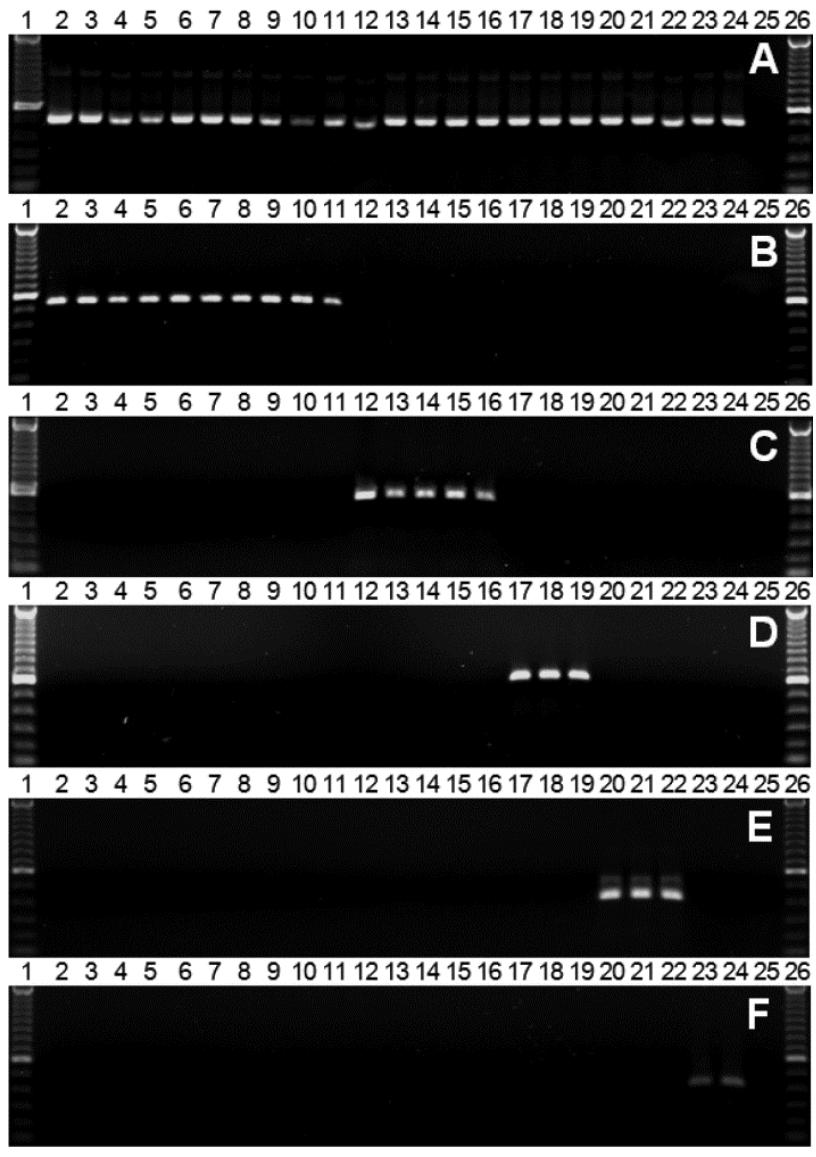

Fig. 1. Polymerase chain reaction detection of different Fusarium spp. with species-specific primer sets. A, Alfie1-GC/2; B, CLOX1/2; C, CLPRO1/2; D, FAC F/R; E, FSOL1/2; and F, Red-F/R. Lanes 1 and 26, GeneRuler 100-bp DNA Ladder; lanes 2 to 11, Fusarium oxysporum; lanes 12 to 16, F. proliferatum; lanes 17 to 19, F. acuminatum; lanes 20 to 22, F solani; lanes 23 to $24, F$ redolens; and lane 25, no DNA (or negative) control.

TABLE 3. Frequency of the Fusarium spp. isolated from asparagus of 11 commercial fields in southwestern Ontario

\begin{tabular}{|c|c|c|c|c|c|c|c|c|c|c|c|}
\hline \multirow[b]{2}{*}{ Fusarium spp. } & \multicolumn{11}{|c|}{ Isolation frequency $(\%)$ on the 11 fields } \\
\hline & 1 & 2 & 3 & 4 & 5 & 6 & 7 & 8 & 9 & 10 & 11 \\
\hline Fusarium acuminatum & 0 & 0 & 13 & 0 & 0 & 0 & 0 & 0 & 0 & 50 & 17 \\
\hline F. oxysporum & 94 & 57 & 37 & 50 & 50 & 75 & 75 & 62 & 62 & 38 & 83 \\
\hline F. proliferatum & 0 & 0 & 37 & 25 & 50 & 12.5 & 12.5 & 38 & 38 & 12 & 0 \\
\hline F. redolens & 0 & 43 & 0 & 0 & 0 & 0 & 0 & 0 & 0 & 0 & 0 \\
\hline F. solani & 6 & 0 & 13 & 25 & 0 & 12.5 & 12.5 & 0 & 0 & 0 & 0 \\
\hline
\end{tabular}


The most pathogenic isolates of the predominant species, $F$. oxysporum, F. proliferatum, and $F$. solani, were $F o-1.5, F p-7.2$, and $F s-1.12$ and their average severity was 76,37 , and $92 \%$, respectively. Based on these results, the isolates $F o-1.5$ and Fs-1.12, with highest pathogenicity, were selected for further experiments.

Soil amendments and microbial assays. The evaluation of the effect of organic soil amendments on FCRR in the first experiment showed that the severity of symptoms on Jersey Giant plants in Fo-1.5-infested soils was very low, and there were no significant differences between the soil treatments (Fig. 5A); whereas, in Fs-1.12-infested soils, stem and root system severity were significantly $(P<0.05)$ reduced by all treatments $($ Fig. $5 \mathrm{~B})$. The highest reduction (93 and $90 \%$ in stem and root severity, respectively) compared with the Fusarium control treatment, for which the severity was moderate, corresponded to PPM at 1\% (Fig. 5B). With the rest of amendments, the stem and root system disease severities were similar to those of benomyl (by $63 \%$ in both stems and roots), the decreases being 71 and $66 \%$ for $0.5 \%$ PPM; 44 to 53 and 55 to $74 \%$ for 3 and $6 \%$ ORC, respectively; and 75 and $82 \%$ in the case of $0.5 \%$ FE (Fig. 5B), respectively. In the second experiment, the severity of symptoms was high in Mary Washington asparagus plants grown in $F o$-1.5-infested soils. Only the $1 \%$ PPM treatment significantly $(P<0.05)$ reduced the symptom severity on the stem (by $42 \%$ ), and the applications of 0.5 and $1 \%$ PPM and 6\% ORC significantly $(P<0.05)$ reduced root severity (by 28 and $44 \%$, and $27 \%$, respectively), compared with the Fusarium control treatment (Fig. 5C). Mary Washington plants grown in $F s$-1.12-infested soils had higher symptom severity than the plants grown in $F O$-1.5-infested soils. Only the benomyl and $0.5 \%$ PPM treatments significantly $(P<0.05)$ reduced severity on the stem (by 22 and 18\%, respectively) compared with the Fusarium control treatment (Fig. 5D); however, there were no significant differences between Fusarium control and amended treatments on root severity of plants in $F s$-1.12-infested soils (Fig. 5D). In the third experiment, where Grande plants were grown in Fs-1.12-infested soils, low severity of aerial symptoms was observed in contrast to the Fusarium control, regardless of the treatment. However, root severity showed a significant $(P<0.05)$ reduction with the application of any treatment; benomyl as well as the soil amendments with $0.5 \% \mathrm{FE}$ and 0.5 and $1 \%$ PPM were the most effective on disease control (100, 97, 95, and 89\% reduction, respectively) compared with the Fusarium control (Fig. 6).

The evaluation of the effect on plant growth in the first experiment showed that both fresh and dry weights of Jersey Giant plants were not affected by any amendment treatments in soils infested with isolate $F o-1.5$ (Fig. 7A). In soils infested with isolate $F s-1.12$, the addition of benomyl and the treatments with 0.5 and $1 \%$ PPM significantly $(P<0.05)$ increased fresh (by 68 ,

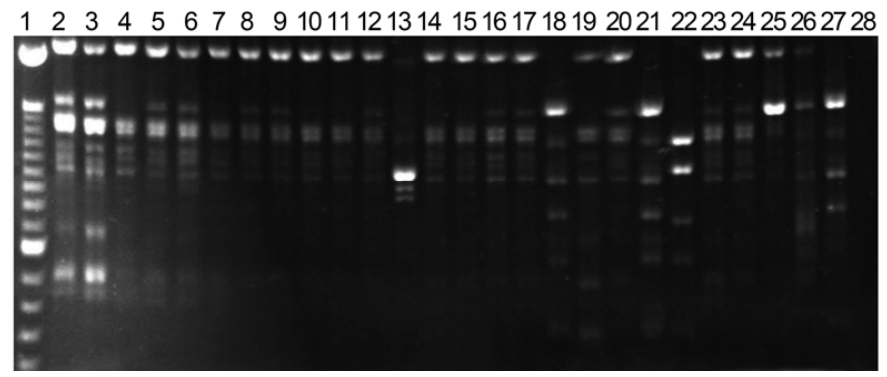

Fig. 2. Agarose gel showing the inter-simple sequence repeats polymerase chain reaction amplification of DNA from different Fusarium spp. with primer (AAG) 6 . Lane 1, GeneRuler 100-bp DNA ladder; lanes 2 to 24, Fusarium field isolates; lanes 25 to 27 , known asparagus-pathogenic isolates (lane 25, F. oxysporum f. sp. asparagi; lane 26, F. proliferatum; and lane 27, F. solani); and lane 28 , no DNA (or negative) control.
81 , and $104 \%$, respectively) and dry (by 64, 55, and 109\%, respectively) weights of Jersey Giant plants compared with the Fusarium control treatment (Fig. 7B). In the second experiment, the 1\% PPM amendment to Fo-1.5-infested soil significantly $(P<$ 0.05 ) increased the fresh (by 77\%) and dry (by 100\%) weights of Mary Washington plants compared with the Fusarium control

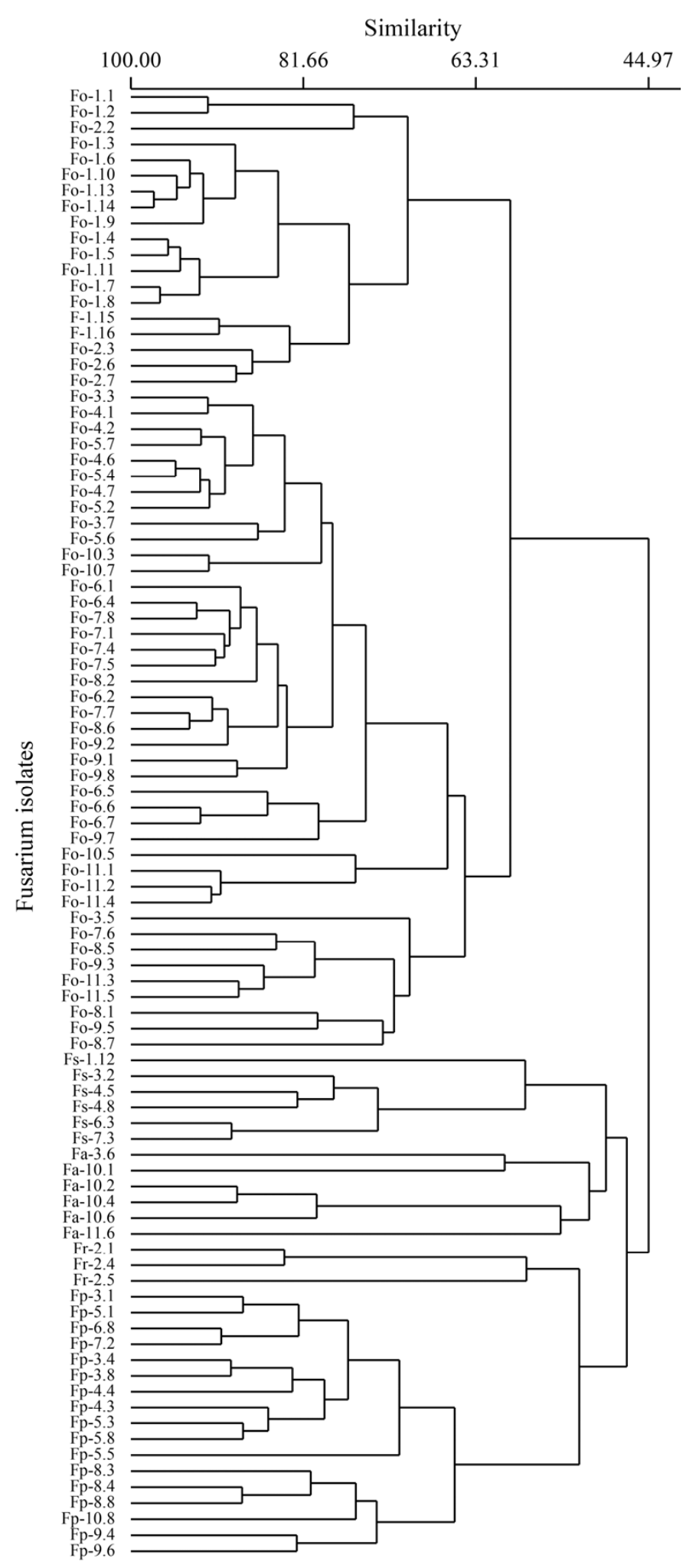

Fig. 3. Dendrogram derived from cluster analysis of similarities between Fusarium isolates from asparagus fields based on inter-simple sequence repeats polymerase chain reaction analysis. Analysis was performed with complete linkage and Euclidean distance options of Minitab statistical software (version 15.1; Minitab Inc., State College, PA). 
treatment (Fig. 7C), and only the benomyl treatment to Fs-1.12infested soil significantly $(P<0.05)$ increased the fresh weight (by 50\%) of Mary Washington plants compared with the $F u$ sarium control treatment (Fig. 7D). In the third experiment, fresh weights of Grande asparagus plants were significantly $(P<0.05)$ higher in soil amended with 0.5 and $1 \%$ PPM, $0.5 \% \mathrm{FE}$, and benomyl, with an increase of 138, 152, 131, and $100 \%$ over the Fusarium control. A similar effect was observed for dry weight of plants, with the highest values corresponding to the three amendments above mentioned (Fig. 8).

In the study of the effect of soil chemical and organic treatments on soil populations of Fusarium (Fo-1.5, Fs-1.12, and other Fusarium spp. present in natural soil), in the first experiment, the Fusarium populations in the treated soils gradually decreased compared with the untreated Fusarium control soils (Fig. 9A and B). In Fo-1.5-infested soils, benomyl, 1\% PPM, and 3\% ORC decreased Fusarium populations after 1 day post treatment; whereas, with $0.5 \%$ PPM, $6 \%$ ORC, and $0.5 \%$ FE treatments, the pathogen population also started to decrease after 7 days compared with the Fusarium control treatment (Fig. 9A). After 14 days of treatment, the reduction in pathogen population was most effective with benomyl and 1\% PPM. In Fs-1.12-infested soils, Fusarium populations were higher and all chemical and amendment treatments gradually decreased the Fusarium populations starting from day 1 after treatments, and the reduction in pathogen populations was most obvious after 14 days with the $1 \%$ PPM, 6\% ORC, and $0.5 \%$ FE amendments $(60,56$, and $62 \%$ reduction, respectively), compared with the Fusarium control treatment (Fig. 9B). In the second experiment, all chemical and amendment treatments to $F o-1.5-$ and $F s$-1.12-infested soil significantly $(P<0.05)$ and gradually decreased the pathogen populations from the day 1 after receiving treatments (Fig. 9C and D). After 14 days, $1 \%$ PPM and benomyl were the most effective treatments in reducing the Fusarium populations in $\mathrm{Fo}_{\mathrm{O}} \mathrm{-1.5}$ - and $F s$-1.12-infested soils, respectively (Fig. 9C and D). In the third experiment, all chemical and amendment treatments significantly $(P<0.05)$ decreased the Fusarium populations in the soil infested with $F s-1.12$ after 10 days (Table 4). The 1\% PPM, benomyl, and $0.5 \%$ FE were the best treatments in reducing the pathogen populations after 66 days of treatment applications (Table 4).

In the study of the effect on soil populations of total culturable bacteria, in the first experiment, the bacterial populations were significantly $(P<0.05)$ higher in the soils treated with the organic amendments than in the Fusarium and chemical control soils (Fig. 10A and B). The highest increase in population of culturable bacteria occurred in $F s$-1.12-infested soils amended with 0.5 and 1\% PPM (19.8 and $15.7 \%$ increase) and 6\% ORC (16.4\% increase) after 14 days of incubation (Fig. 10B). In the second experiment, the populations of culturable bacteria were also significantly higher in soils treated with organic amendments compared with the Fusarium and chemical control soils (Fig. 10C and D). All organic amendment treatments were equally effective in increasing the populations of culturable bacteria. After 14 days of incubation, an average increase of 14.6 to $19.4 \%$ was observed with organic amendments (Fig. 10C and D). In the third experi-

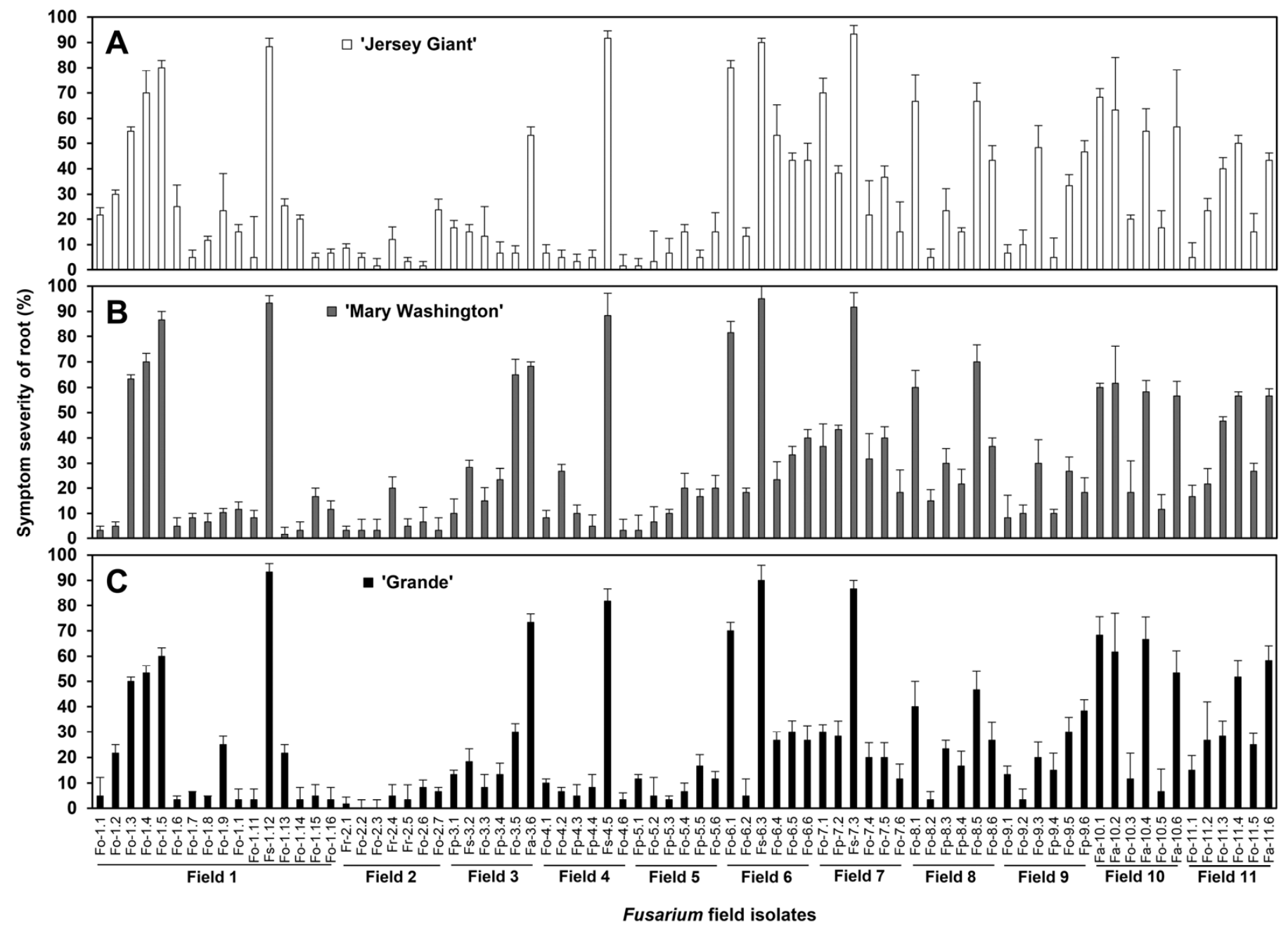

Fig. 4. Severity of root symptoms on the seedlings of the three asparagus cultivars A, 'Jersey Giant'; B, 'Mary Washington'; and C, 'Grande' inoculated with field isolates of Fusarium spp. Error bars represent standard error. 
ment, the populations of total culturable bacteria were significantly $(P<0.05)$ higher in the soils treated with organic amendments (by $9 \%$ at least) than in the Fusarium and chemical control soils, where the population decreased rapidly after 10 days of treatment (Table 4).

The determination of the effect on soil $\mathrm{pH}$ in the first experiment showed that soil amendments of 3 and 6\% ORC increased soil $\mathrm{pH}$ after 1 day of treatment and $\mathrm{pH}$ stayed above throughout the 14-day incubation period (Fig. 11A). The soil pH also increased immediately after the $0.5 \%$ FE treatment but decreased after 3 days (Fig. 11A). Similar trends were also seen with ORC and FE treatments in $F s$-1.12-infested soils (Fig. 11B). The $1 \%$ PPM treatment also increased the $\mathrm{pH}$ after 1 day of incubation in this experiment (Fig. 11B). All other treatments had no significant effect on soil $\mathrm{pH}$ during the entire incubation period. In the second experiment in soils infested with isolate $F o-1.5$, the $\mathrm{pH}$ increased significantly after 1 day of incubation in soils treated with 3 and 6\% ORC and 1\% PPM (Fig. 11C). A sharp decrease in $\mathrm{pH}$ of the soil treated with $0.5 \%$ FE after 7 days was also noticed in this experiment (Fig. 11C). A similar trend in soil $\mathrm{pH}$ was also noticed in $F s$-1.12-infested soils, except that 1\% PPM significantly decreased the $\mathrm{pH}$ after 7 days and $0.5 \%$ FE decreased $\mathrm{pH}$ after 3 days (Fig. 11D). The soil $\mathrm{pH}$ was not affected by any other treatments during the entire incubation period. In the third experiment in soils infested with isolate $F s-1.12$, the 3 and $6 \%$ ORC treatments increased soil $\mathrm{pH}$ after 3 days of incubation

TABLE 4. Effect on population of isolate $F s-1.12$ and total culturable bacteria, and on soil $\mathrm{pH}^{\mathrm{y}}$

\begin{tabular}{|c|c|c|c|c|c|c|c|c|c|c|}
\hline \multirow[b]{3}{*}{ Treatment $^{z}$} & \multicolumn{6}{|c|}{ Log CFU/g of soil } & & & & \\
\hline & \multicolumn{3}{|c|}{ Isolate $F s-1.12$} & \multicolumn{3}{|c|}{ Total culturable bacteria } & \multicolumn{4}{|c|}{ Soil pH } \\
\hline & 0 day & 10 days & 66 days & 0 day & 10 days & 66 days & 0 day & 3 days & 7 days & 10 days \\
\hline \multicolumn{11}{|l|}{ Controls } \\
\hline Negative & $1.09 \mathrm{o}$ & $1.16 \mathrm{no}$ & $1.27 \mathrm{n}$ & $7.53 \mathrm{i}$ & $7.61 \mathrm{~g}$ & $7.68 \mathrm{~h}$ & $7.11 \mathrm{gh}$ & $7.13 \mathrm{fgh}$ & $7.09 \mathrm{gh}$ & $7.10 \mathrm{gh}$ \\
\hline Fusarium & $6.94 \mathrm{a}$ & $6.33 c$ & $6.65 \mathrm{~b}$ & $8.39 \mathrm{f}$ & 8.12 ef & $7.93 \mathrm{~g}$ & $7.15 \mathrm{fg}$ & $7.16 \mathrm{efg}$ & $7.15 \mathrm{fg}$ & $7.13 \mathrm{fgh}$ \\
\hline Chemical & $6.94 \mathrm{a}$ & $3.13 \mathrm{j}$ & $2.22 \mathrm{~m}$ & $8.39 \mathrm{f}$ & 7.73 cde & $7.55 \mathrm{~h}$ & $7.15 \mathrm{fg}$ & $7.13 \mathrm{fgh}$ & $7.17 \mathrm{efg}$ & $7.12 \mathrm{fgh}$ \\
\hline PPM $0.5 \%$ & $6.94 \mathrm{a}$ & $4.46 \mathrm{e}$ & $2.99 \mathrm{k}$ & $8.39 \mathrm{f}$ & $9.14 \mathrm{bcd}$ & $9.06 \mathrm{ab}$ & $7.15 \mathrm{fg}$ & $7.16 \mathrm{fgh}$ & $7.19 \mathrm{efg}$ & $7.04 \mathrm{~h}$ \\
\hline PPM $1 \%$ & $6.94 \mathrm{a}$ & $3.33 \mathrm{i}$ & $2.19 \mathrm{~m}$ & $8.39 \mathrm{f}$ & $9.28 \mathrm{de}$ & $8.87 \mathrm{abc}$ & $7.15 \mathrm{fg}$ & $7.32 \mathrm{~cd}$ & $7.42 \mathrm{bc}$ & $7.22 \mathrm{def}$ \\
\hline ORC $1 \%$ & $6.94 \mathrm{a}$ & $4.82 \mathrm{~d}$ & $3.53 \mathrm{~h}$ & $8.39 \mathrm{f}$ & $9.26 \mathrm{def}$ & $9.10 \mathrm{ab}$ & $7.15 \mathrm{fg}$ & $7.40 \mathrm{bc}$ & $7.48 \mathrm{bc}$ & $7.50 \mathrm{~b}$ \\
\hline ORC 3\% & $6.94 \mathrm{a}$ & $3.96 \mathrm{f}$ & $3.35 \mathrm{i}$ & $8.39 \mathrm{f}$ & $9.10 \mathrm{de}$ & $8.91 \mathrm{abcd}$ & $7.15 \mathrm{fg}$ & $7.64 \mathrm{a}$ & $7.71 \mathrm{a}$ & $7.67 \mathrm{a}$ \\
\hline FE $0.1 \%$ & $6.94 \mathrm{a}$ & $4.81 \mathrm{~d}$ & $3.84 \mathrm{~g}$ & $8.39 \mathrm{f}$ & 8.86 ef & $8.79 \mathrm{~cd}$ & $7.15 \mathrm{fg}$ & $7.21 \mathrm{ef}$ & $7.12 \mathrm{efg}$ & $6.90 \mathrm{i}$ \\
\hline FE $0.5 \%$ & $6.94 \mathrm{a}$ & $3.83 \mathrm{~g}$ & 2.821 & $8.39 \mathrm{f}$ & $9.00 \mathrm{de}$ & $9.13 \mathrm{a}$ & $7.15 \mathrm{fg}$ & $7.27 \mathrm{de}$ & $6.92 \mathrm{i}$ & $6.78 \mathrm{j}$ \\
\hline
\end{tabular}

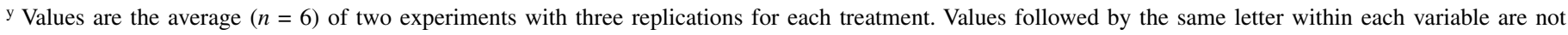
significantly different according to the least significant difference test $(P \leq 0.01)$.

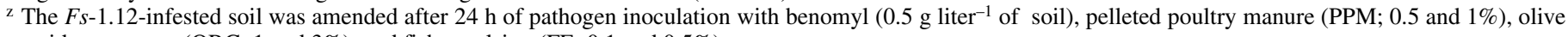
residue compost (ORC; 1 and 3\%), and fish emulsion (FE; 0.1 and $0.5 \%$ ).

Isolate $\mathrm{Fo}-1.5$

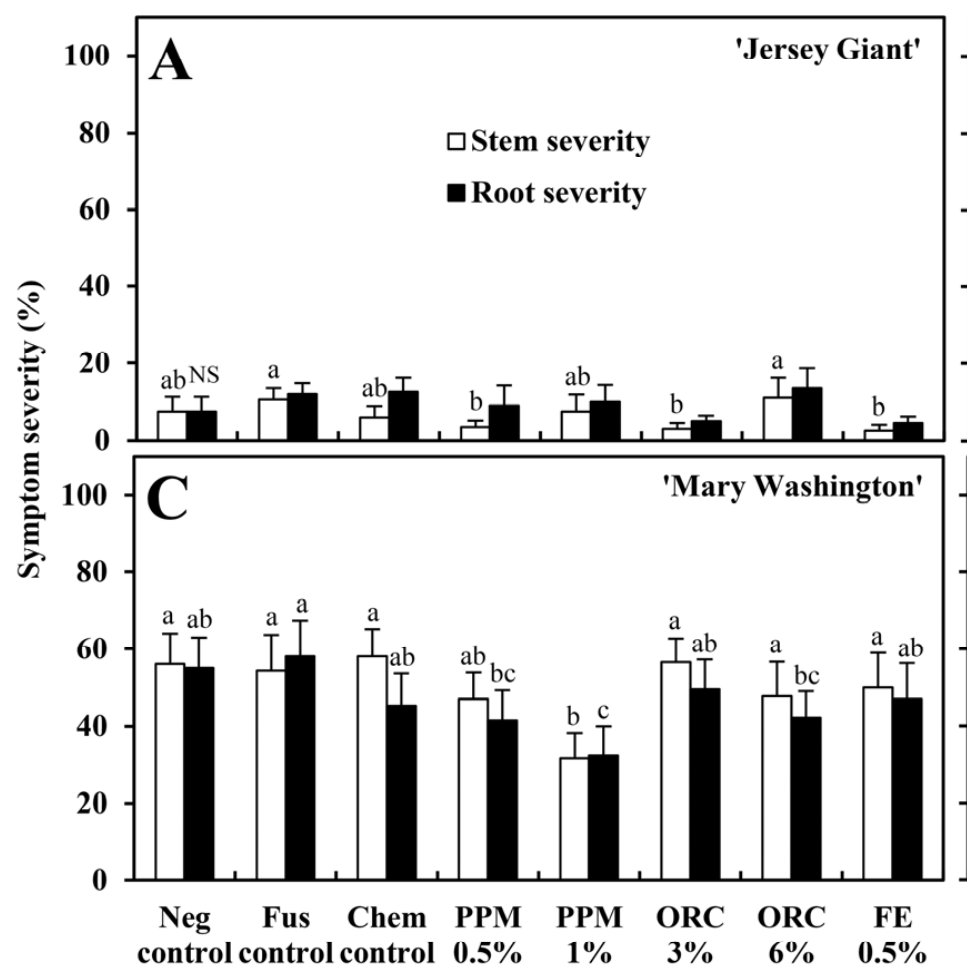

Isolate $F s-1.12$

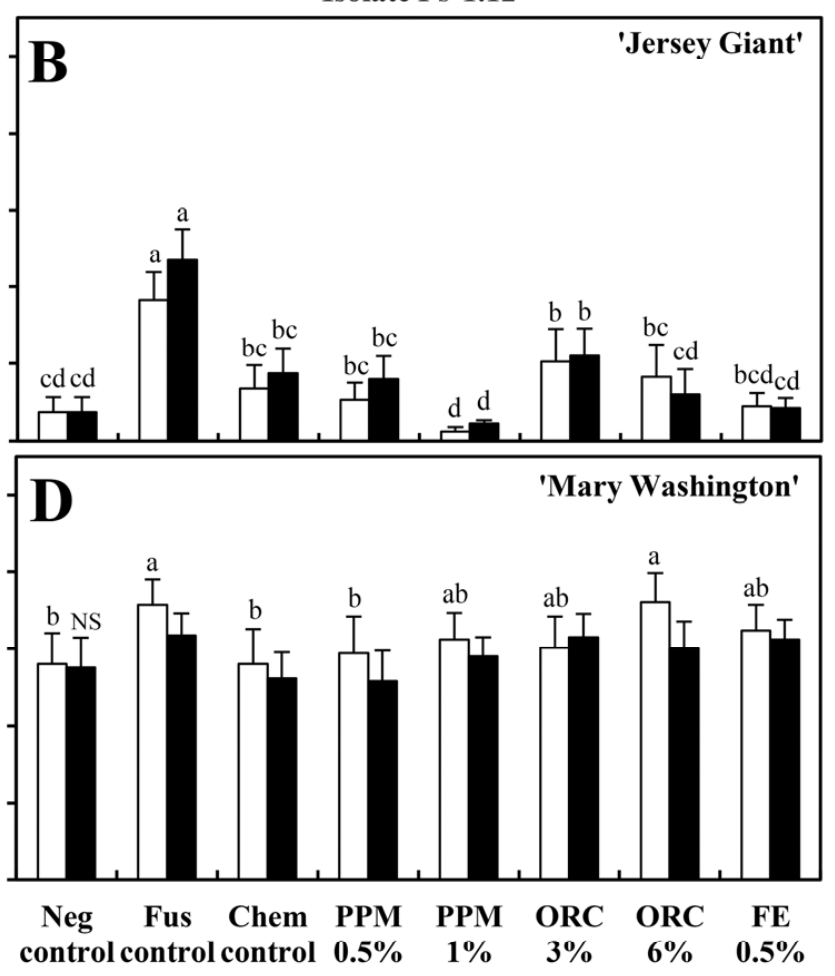

Treatments

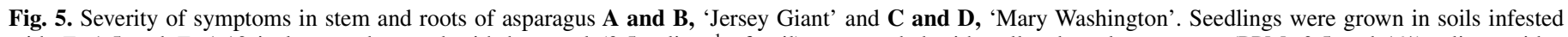

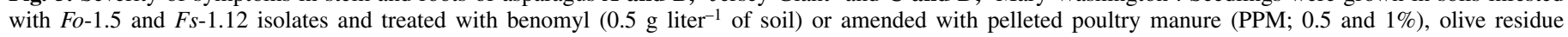

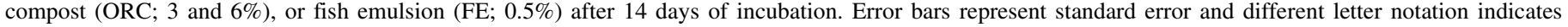

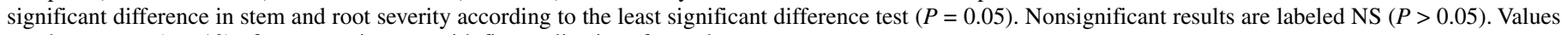
are the average $(n=10)$ of two experiments, with five replications for each treatment. 
(Table 4). The soil $\mathrm{pH}$ was also increased with the 1\% PPM treatment but, after 7 days, it decreased. With the addition of 0.5 and $0.1 \% \mathrm{FE}$, the $\mathrm{pH}$ significantly decreased after 7 and 10 days of incubation, respectively (Table 4).

\section{DISCUSSION}

FCRR is an important disease of asparagus with a very complex etiology, because several soilborne Fusarium spp. are

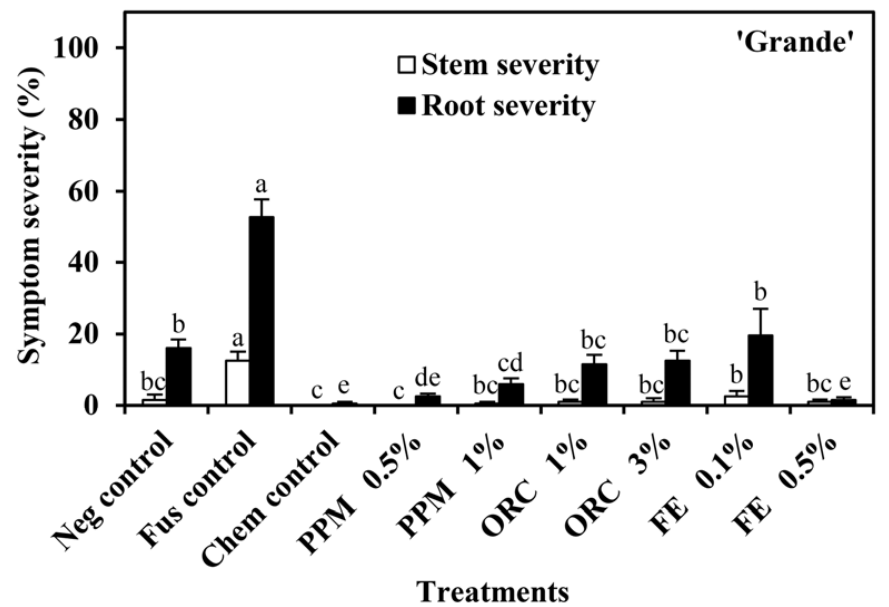

Fig. 6. Severity of symptoms in stem and root of asparagus 'Grande'. Seedlings were grown in $F s$-1.12-infested soils treated with benomyl $(0.5 \mathrm{~g}$ liter $^{-1}$ of soil) or amended with pelleted poultry manure (PPM; 0.5 and $1 \%$ ), olive residue compost (ORC; 1 and 3\%), or fish emulsion (FE; 0.1 and $0.5 \%$ ) after 10 days of incubation. Error bars represent standard error and different letter notation indicates significant difference according to the least significant difference test $(P=0.05)$. Values are the average $(n=10)$ of two experiments, with five replications for each treatment. associated as causal agents and have been frequently isolated from the affected plants. This disease is also known as one of the contributing factors in asparagus decline. In this study, 93 isolates of Fusarium spp. collected form 11 established asparagus fields with a history of FCRR in southwestern Ontario were identified based on morphological characteristics and PCR analysis with species-specific primers. Their identity was confirmed as $F$. acuminatum, $F$. oxysporum, $F$. proliferatum, $F$. redolens, and $F$. solani. Only $F$. oxysporum was found in all investigated fields and

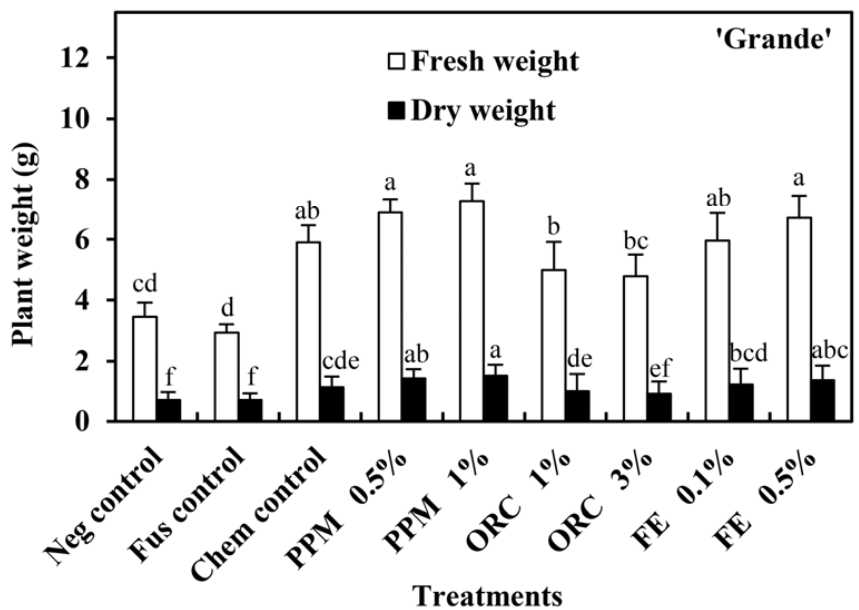

Fig. 8. Plant fresh and dry weights of 'Grande' asparagus. Seedlings were grown in $F s$-1.12-infested soils treated with benomyl $\left(0.5 \mathrm{~g} \mathrm{liter}^{-1}\right.$ of soil) or amended with pelleted poultry manure (PPM; 0.5 and $1 \%$ ), olive residue compost (ORC; 1 and 3\%), or fish emulsion (FE; 0.1 and $0.5 \%$ ) after 10 days of incubation. Error bars represent standard error and different letter notation indicates significant difference according to the least significant difference test $(P=0.05)$. Values are the average $(n=10)$ of two experiments, with five replications for each treatment.
Isolate $\mathrm{Fo}-1.5$

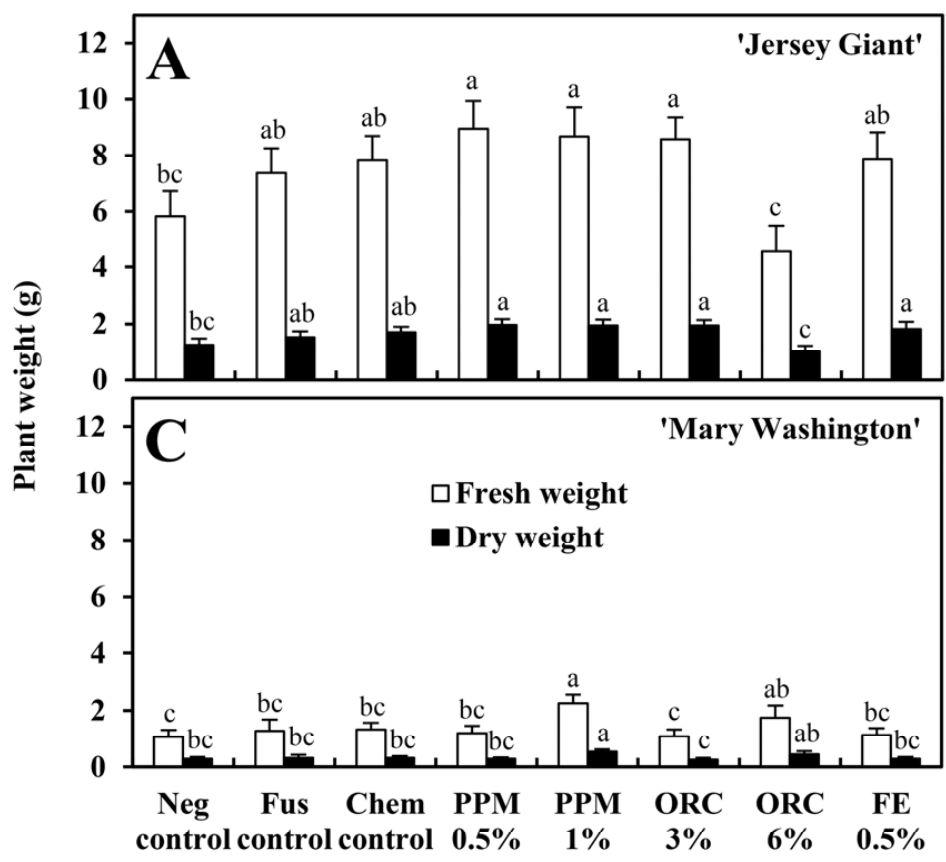

Isolate $F s-1.12$

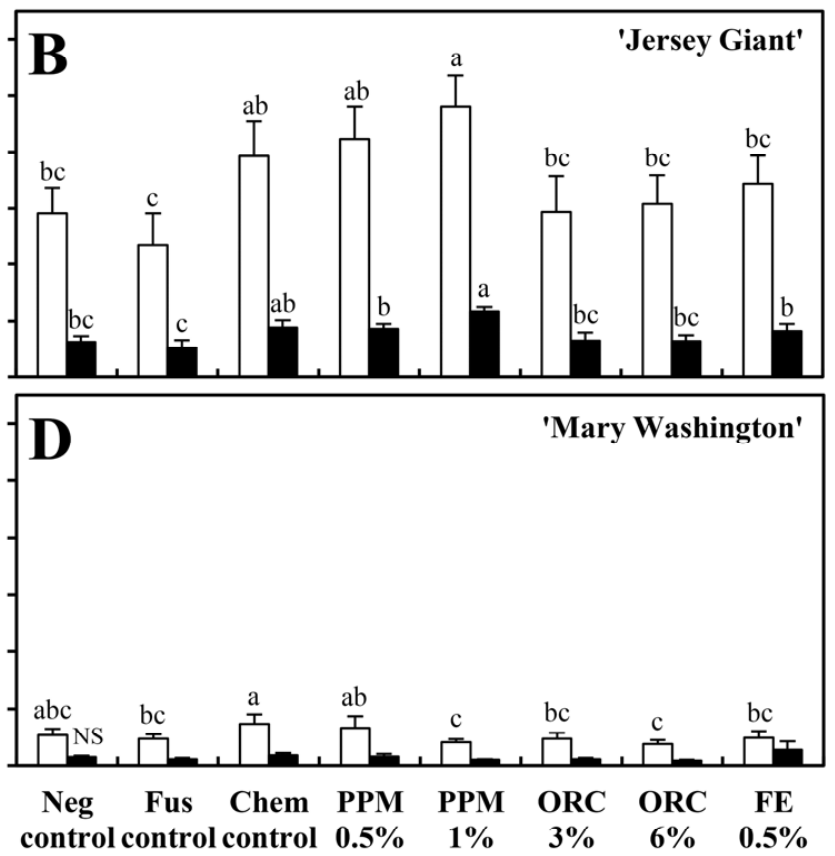

Treatments

Fig. 7. Plant fresh and dry weights of asparagus $\mathbf{A}$ and B, 'Jersey Giant' and $\mathbf{C}$ and D, 'Mary Washington'. Seedlings were grown in soils infested with Fo-1.5 and Fs-1.12 isolates and treated with benomyl $\left(0.5 \mathrm{~g} \mathrm{liter}^{-1}\right.$ of soil) or amended with pelleted poultry manure (PPM; 0.5 and $\left.1 \%\right)$, olive residue compost (ORC; 3 and $6 \%$ ), or fish emulsion (FE; $0.5 \%$ ) after 14 days of incubation. Error bars represent standard error and different letter notation indicates significant difference in stem and root severity according to the least significant difference test $(P=0.05)$. Nonsignificant results are labeled NS $(P>0.05)$. Values are the average $(n=10)$ of two experiments, with five replications for each treatment. 
Isolate $\mathrm{Fo}-1.5$

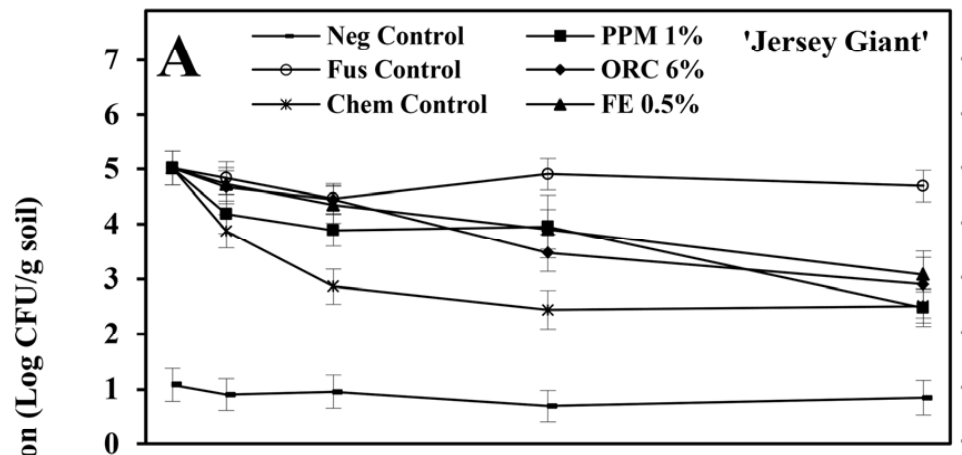

产
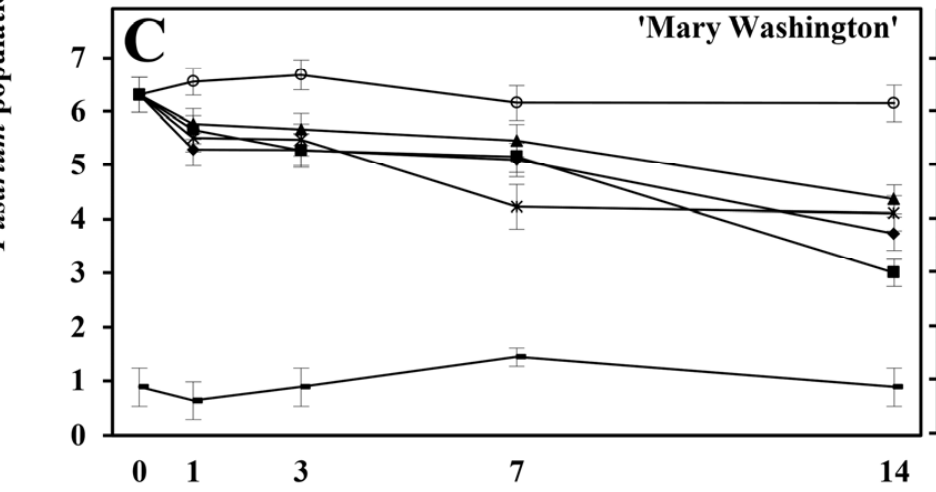

Fig. 9. Population of Fusarium isolates Fo-1.5 and Fs-1.12 in asparagus A and B, 'Jersey Giant' and C and D, 'Mary Washington' experiments at 1, 3, 7, and 14 days after infestation. Infested soils were treated with benomyl $\left(0.5 \mathrm{~g} \mathrm{liter}^{-1}\right.$ of soil) or amended with pelleted poultry manure (PPM; $\left.1 \%\right)$, olive residue compost (ORC; 6\%), or fish emulsion (FE; 0.5\%) $24 \mathrm{~h}$ after infestation. Values are expressed as $\log \mathrm{CFU} \mathrm{g}{ }^{-1}$ of soil and are the average $(n=6)$ of two experiments, with three replications for each treatment.

Isolate Fo-1.5
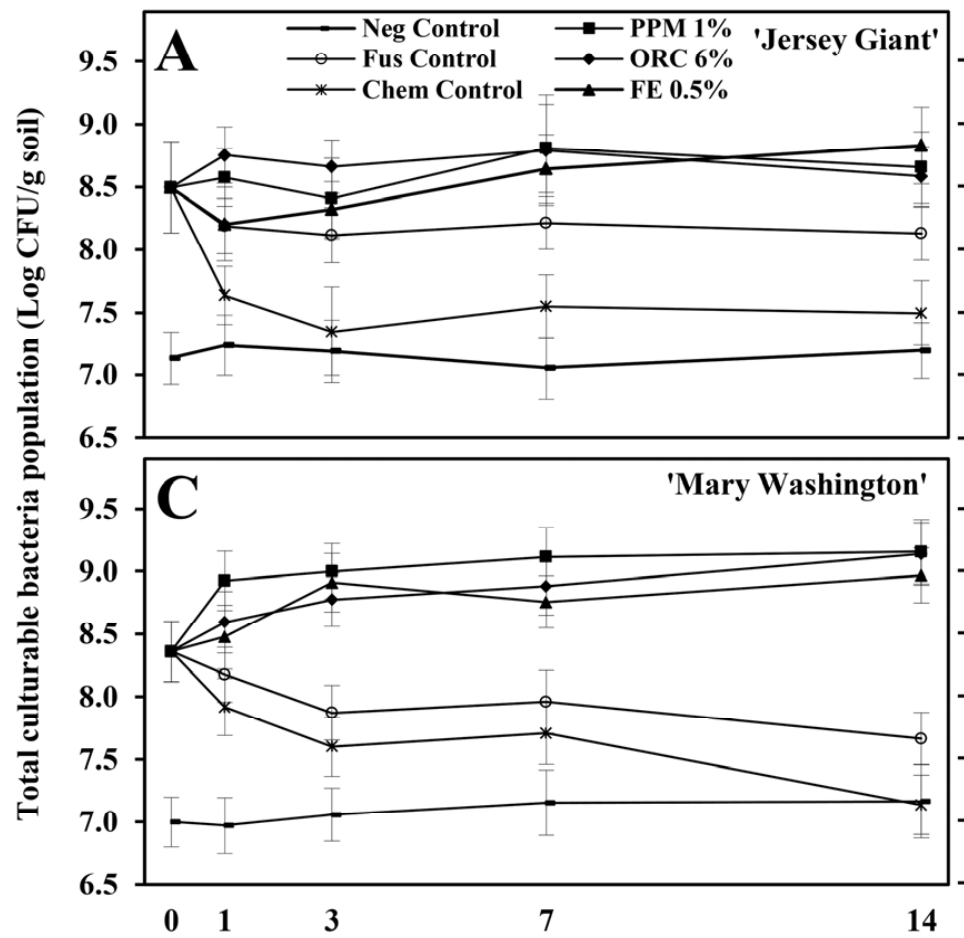
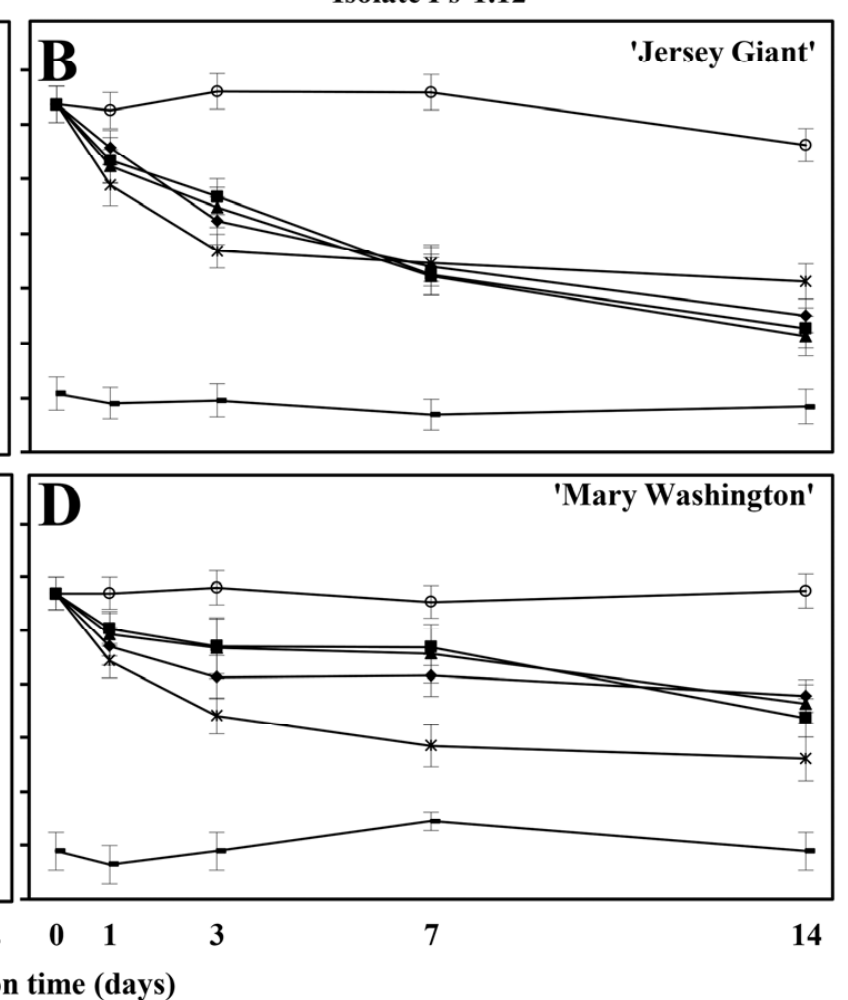

$$
14
$$


was the most frequently isolated, representing $\approx 65.5 \%$ of all Fusarium isolates. F. proliferatum represented $18.3 \%$ and the rest of the Fusarium spp. were much less frequent $(<6.5 \%)$. Further characterization of these field isolates by ISSR-PCR analysis revealed considerable variability between the isolates belonging to different Fusarium spp.

The diversity of Fusarium spp. associated with asparagus has been reported from Canada (54) and other countries $(15,40,57)$. There was a large dissimilarity in the dominant species of Fusarium between different regions or continents. In a previous study on the diversity of Fusarium spp. from asparagus fields in eastern Canada, Vujanovic et al. (54) found $F$. oxysporum and $F$. proliferatum as predominant and abundant, whereas $F$. redolens, $F$. solani, and $F$. acuminatum were less frequently found, with $F$. redolens being the third most frequent in the area of Quebec and $F$. solani and F. acuminatum more common in Ontario. Similar to our results, the frequency of isolation in asparagus fields in Japan was $68,28.6$, and $2.5 \%$ for $F$. oxysporum, $F$. proliferatum, and $F$. solani, respectively, but $F$. redolens was absent (40). A similar frequency pattern was found in asparagus fields in the United Kingdom and Spain (57). However, isolations from asparagus nurseries in Spain indicated high frequencies of $F$. proliferatum, F. oxysporum, and $F$. verticillioides (syn. F. moniliforme) (15).

The recovery of Fusarium spp. is strongly influenced by host organ; for example, generally, $F$. proliferatum infects mainly the crown and other Fusarium spp., such as $F$. oxysporum, colonize in roots. Therefore, the plant portion affects the isolation rate of Fusarium spp. $(17,20)$. In our study, due to the greater surface of roots than surface of crown (or rhizome) existing in the whole root system of asparagus plants, the ratio of root pieces sampled (including storage and secondary roots) was higher than the proportion of crown pieces (ratio of 1.5:1). This could explain the higher percentage of $F$. oxysporum in the 11 fields. Accordingly, most of the 93 Fusarium isolates were recovered mainly from roots $(53 \%)$ and crowns $(24 \%)$. The diversity and abundance of
Fusarium spp. can also be influenced by available soil nutrients (60) as well as by other abiotic and biotic factors (59).

The results of pathogenicity assessment showed a wide range in virulence among the Fusarium field isolates. F. oxysporum, $F$. solani, and $F$. acuminatum were highly pathogenic, whereas $F$. proliferatum and $F$. redolens were found to be weakly virulent. However, other studies reported different results in the virulence of isolates. Blok and Bollen (7) found F. oxysporum to be the most important virulent species in asparagus in the Netherlands, whereas extremely virulent isolates of $F$. solani were associated with asparagus in Spain and the percentage of $F$. proliferatum isolates associated with root dry weight loss was high (15). In Japan, the United Kingdom, and Spain, F. oxysporum f. sp. asparagi and $F$. proliferatum were the species most frequently associated with diseased asparagus plants and are considered important biotic factors for asparagus decline in those countries $(40,57)$. In this study, $F$. oxysporum and $F$. proliferatum were the predominant species but the virulence determined by pathogenicity tests also showed the importance of $F$. solani (45\% isolation frequency); thus, these three species can be considered the most important species of Fusarium associated with the FCRR of asparagus fields in southwestern Ontario. The results of this study also showed a similar level of susceptibility in the three cultivars to FCRR. However, in the greenhouse bioassays, Jersey Giant and Grande were less susceptible to FCRR than Mary Washington. Both in vitro pathogenicity tests and greenhouse control bioassays confirmed that the $F$. solani field isolate $F s-1.12$ was consistently more aggressive and caused severe FCRR symptoms on all three asparagus cultivars compared with the $F$. oxysporum isolate Fo-1.5.

The greenhouse studies indicated that PPM, ORC, and FE as preplant soil amendments reduced stem and root system severity of FCRR on asparagus, and disease reduction in most cases was more conspicuous in the moderately susceptible Jersey Giant and Grande than in the most susceptible Mary Washington. All three
Isolate $\mathrm{Fo}-1.5$

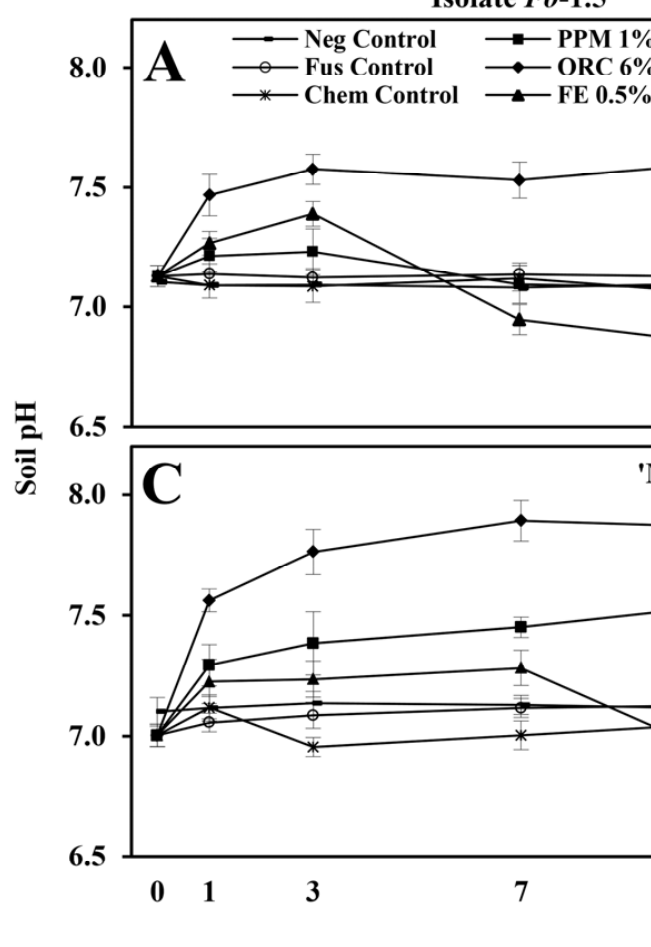

Isolate $F s-1.12$

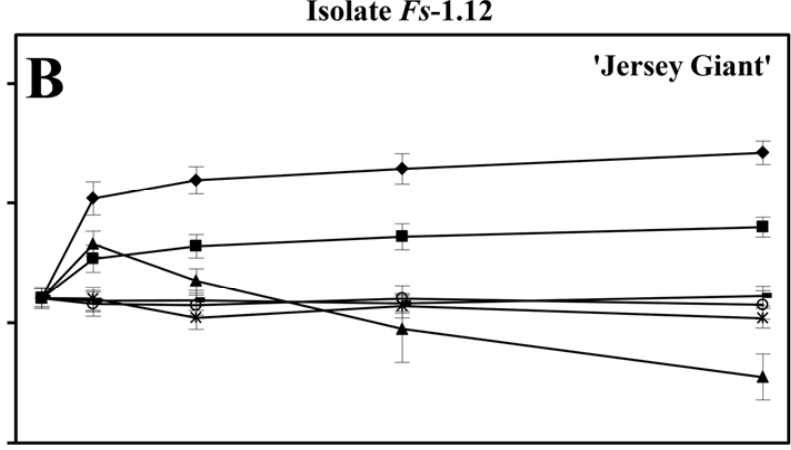

D

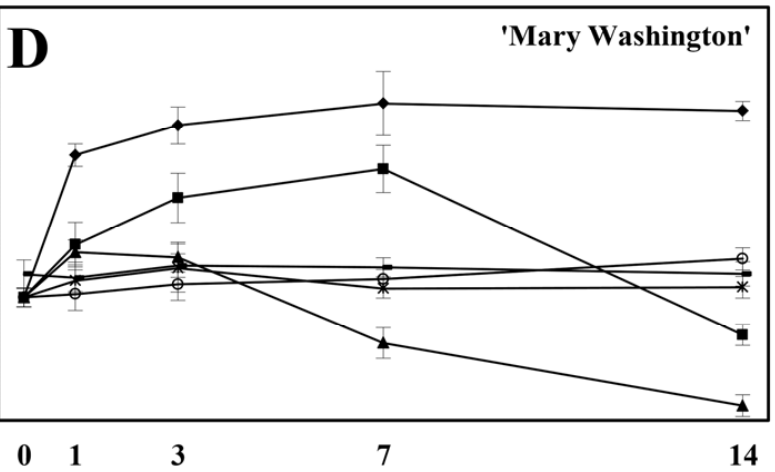

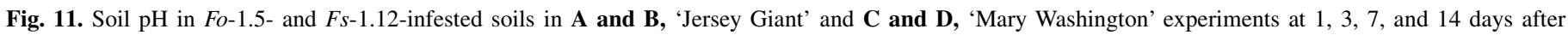

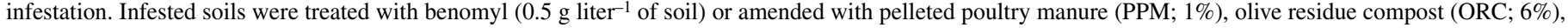

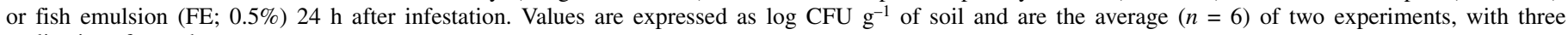
replications for each treatment. 
organic products also increased fresh and dry plant weights, and the biomass increase was associated with reductions in symptoms severity and was higher when the moderately susceptible cultivars were grown in $F$. solani $F s$-1.12-infested soil. The results of the study also showed a gradual decline in Fusarium populations in contrast with a steady increase in the population densities of total culturable bacteria in soils amended with each of the three organic products. This was more frequent at the highest rates of organic amendments used. Furthermore, these higher amendment rates were also most effective in reducing FCRR severity and increasing plant weights.

Soil organic amendments can play an important role in disease control and plant growth promotion, possibly by reducing the pathogen inoculum, an argument supported by our current study as well as some previous reports. Borrego et al. (12) found a reduction in the viability of $F$. oxysporum f. sp. asparagi inoculum in the soils amended with PPM and ORC and incubated for several weeks at 30 and $35^{\circ} \mathrm{C}$ prior to planting in greenhouse pot experiments. They also found a reduction in disease severity and an increase in plant growth when asparagus seedlings were planted in such soils after the end of the incubation period. Similarly, a reduction in soil populations of $F$. oxysporum, $F$. solani, and $F$. equiseti in sweet pepper was achieved after solarization of the soils amended with fresh sheep and chicken manure (36). Soil amendment of poultry manure or compost reduced the severity and impact of Fusarium wilt on strawberry (25) and carnation (37), and soil amendment of ORC improved suppressiveness against $F$. oxysporum f. sp. radicis-lycopersici and Phytophthora nicotianae in tomato (44). Dairy compost enhanced crop yield, spear number, and microbial biomass in the asparagus fields with replant problems (41), and soil amendment of FE improved disease suppressiveness against seedling dampingoff and root rots, potato scab, and Verticillium wilt diseases (1-3). In most of these cases, disease control by organic soil amendments was reciprocated with an increased microbial activity in the amended soil.

On the other hand, depending on the rates and types of soil organic amendments used, toxic metabolites released during the bacterial breakdown of some organic products in the soil may also have played a role in disease suppression. Poultry manures are nitrogen-rich amendments that can eliminate many plant pathogens due to the release and accumulation of compounds such as $\mathrm{NH}_{3}$ and $\mathrm{HNO}_{2}$ that can be toxic to plant pathogens $(49,50)$. Composts made of olive residues used as plant growth substrates were found to reduce the effects of $F$. oxysporum $\mathrm{f}$. sp. radicis-lycopersici (44) but this was related to interactions between soil abiotic characteristics, changes in microbial populations, and, perhaps, the reduced susceptibility of the plants $(4,13,44)$. Organic byproducts used in this study may have provided disease control and plant growth promotion, possibly by decreasing pathogen populations and enhancing total bacterial activity as well as the activity of fungal antagonists (not determined in this study) in the soil. Any role of toxic compounds is less likely but cannot be overruled.

Another possible mechanism for disease suppression is competition between soil microorganisms and Fusarium spp. The addition of organic amendments to soil strongly influences the soil microflora (23). In our study, only populations of total culturable bacteria were determined but the densities of beneficial or deleterious fungi were not reflected. Thus, in the Fusarium spp.infested soils incubated for $24 \mathrm{~h}$ prior to the treatments, an increase in total culturable bacteria was observed in those infested soils compared with the noninfested soils. After the addition of all organic amendments, the bacterial activity gradually and continuously increased in these amended soils. This result supports previous reports, where the use of compost on asparagus fields enhanced the soil bacterial biomass (41) and the use of FE caused the increment of bacteria in soil or substrate (1). Moreover, these reports also showed an increase in the fungal antagonists. Fungal and bacterial antagonists are reported to play a role in Fusarium population structure, which is strongly influenced by soil nutrient availability such as $\mathrm{P}$ fertilization and $\mathrm{Mn}, \mathrm{Fe}, \mathrm{Ca}$, and dehydrogenase activity (60). However, abiotic factors (soil structure, organic content, $\mathrm{NH}_{4}, \mathrm{Na}$, and $\mathrm{Cu}$ ) have more influence on Fusarium spp. abundance (59). Thus, soil microbial structure could be an important factor in controlling FCRR (29).

In conclusion, the use of agricultural and fish-processing industry byproducts such as PPM, ORC, and FE as soil amendments was found to be an effective method to decrease FCRR severity in asparagus while significantly reducing dependency on chemical pesticides and fertilizers for achieving sustainable production. Our results indicated that organic products such as PPM could be considered in integrated disease management for their effectiveness in decreasing pathogen population and, consequently, disease severity, and promoting plant growth. In addition, we showed the bacterial activity as a response after application of amendments but the role of other microbial groups such as fungi should be also considered. The use of these organic byproducts for management of FCRR needs to be investigated in fields with replant problems. Moreover, the accurate and reliable identification and characterization of Fusarium spp. in fields using DNA-based PCR methods can be important for the development of effective control strategies.

\section{ACKNOWLEDGMENTS}

This research was funded by Agriculture and Agri-Food Canada, by a JAEPredoc-CSIC grant to A. Borrego-Benjumea, and by projects INIA RTA 2006-00045 (Ministerio de Agricultura, Alimentación y Medio Ambiente, Spain) and P06-AGR-02313 (Consejería de Economía, Innovación y Ciencia, Junta de Andalucía). We thank S. Pandurangan, B. Weselowski, and I. Lalin for their technical assistance; and several asparagus growers from Ontario for allowing us to collect soil and plant samples from their farms.

\section{LITERATURE CITED}

1. Abbasi, P. A., Conn, K. L., and Lazarovits, G. 2004. Suppression of Rhizoctonia and Pythium damping-off of radish and cucumber seedlings by addition of fish emulsion to peat mix or soil. Can. J. Plant Pathol. 26:177-187.

2. Abbasi, P. A., Conn, K. L., and Lazarovits, G. 2006. Effect of fish emulsion used as a preplanting soil amendment on Verticillium wilt, scab, and tuber yield of potato. Can. J. Plant Pathol. 28:509-518.

3. Abbasi, P. A., Lazarovits, G., and Jabaji-Hare, S. 2009. Detection of high concentrations of organic acids in fish emulsion and their role in pathogen or disease suppression. Phytopathology 99:274-281

4. Avilés, M., Borrero, C., and Trillas, M. I. 2011. Review on compost as an inducer of disease suppression in plants grown in soilless culture. Pages 1-11 in: Compost III. Dynamic Soil, Dynamic Plant 5 (Special Issue 2). A. S. Ferrer, ed. Global Science Books, Ikenobe, Japan.

5. Barnett, H. L., and Hunter, B. B. 1998. Illustrated Genera of Imperfect Fungi, 4th ed. American Phytopathological Society Press, St. Paul, MN.

6. Bayraktar, H., and Dolar, F. S. 2011. Molecular identification and genetic diversity of Fusarium species associated with onion fields in Turkey. J. Phytopathol. 159:28-34.

7. Blok, W. J., and Bollen, G. J. 1995. Fungi on the roots and stem bases of asparagus in the Netherlands: species and pathogenicity. Eur. J. Plant Pathol. 101:15-24.

8. Blok, W. J., and Bollen, G. J. 1997. Host specificity and vegetative compatibility of Dutch isolates of Fusarium oxysporum f. sp. asparagi. Can. J. Bot. 75:383-393.

9. Blok, W. J., Lamers, J. G., Termorshuizen, A. J., and Bollen, G. J. 2000. Control of soilborne plant pathogens by incorporating fresh organic amendments followed by tarping. Phytopathology 90:253-259.

10. Bogale, M., Wingfield, B. D., Wingfield, M. J., and Steenkamp, E. T. 2007. Species-specific primers for Fusarium redolens and a PCR-RFLP technique to distinguish among three clades of Fusarium oxysporum. FEMS Microbiol. Lett. 271:27-32.

11. Bonanomi, G., Antignani, V., Pane C., and Scala, F., 2007. Suppression of soilborne fungal diseases with organic amendments. J. Plant Pathol. 89:311-324. 
12. Borrego-Benjumea, A., Melero-Vara, J. M., and Basallote-Ureba, M. J. 2010. Effects of soil organic amendments and incubation temperature on the control of Fusarium oxysporum f. sp. asparagi. Acta Hortic. 883:369-375.

13. Borrero, C., Trillas, M. I., Ordovás, J., Tello, J. C., and Avilés, M., 2004. Predictive factors for the suppression of Fusarium wilt of tomato in plant growth media. Phytopathology 94:1094-1101.

14. Burgess, L. W., Summerell, B. A., Bullock, S., Gott, K. P., and Backhouse, D. 1994. Laboratory Manual for Fusarium Research, 3rd ed. University of Sydney, Sydney, NSW, Australia.

15. Corpas-Hervias, C., Melero-Vara, J. M., Molinero-Ruiz, M. L., ZureraMunoz, C., and Basallote-Ureba, M. J. 2006. Characterization of isolates of Fusarium spp. obtained from asparagus in Spain. Plant Dis. 90:14411451.

16. Counts, J. W., and Hausbeck, M. K. 2008. Strategies for managing Fusarium crown and root rot on asparagus. Acta Hortic. 776:167-173.

17. Elmer, W. H. 2001. Fusarium diseases of asparagus. Pages 248-262 in: Fusarium Paul E. Nelson Memorial Symposium. B. A. Summerell, J. F. Leslie, D. Backhouse, W. L. Bryden, and L. W. Burgess, eds. American Phytopathological Society Press, St. Paul, MN.

18. Elmer, W. H. 2002. Influence of formononetin and $\mathrm{NaCl}$ on mycorrhizal colonization and Fusarium crown and root rot of asparagus. Plant Dis. 86:1318-1324.

19. Elmer, W. H. 2004. Combining nonpathogenic strains of Fusarium oxysporum with sodium chloride to suppress Fusarium crown rot of asparagus in replanted fields. Plant Pathol. 53:751-758.

20. Elmer, W. H., Johnson, D. A., and Mink, G. I. 1996. Epidemiology and management of the diseases causal to asparagus decline. Plant Dis. 80:117-125.

21. Elmer, W. H., and Pignatello, J. J. 2011. Effect of biochar amendments on mycorrhizal associations and Fusarium crown and root rot of asparagus in replant soils. Plant Dis. 95:960-966.

22. Elmer, W. H., and Stephens, C. T. 1989. Classification of Fusarium oxysporum f. sp. asparagi into vegetatively compatible groups. Phytopathology 79:88-93.

23. Escuadra, G. M. E., and Amemiya, Y. 2008. Suppression of Fusarium wilt of spinach with compost amendments. J. Gen. Plant Pathol. 74:267-274.

24. Falloon, P. G., Fraser, H., and Nikologg, A. S. 1989. Control of Fusarium rot with thiabendazole. Final Report. Crop Research Division, DSIR, Christchurch, NZ.

25. Fang, X., You, M. P., and Barbetti, M. J. 2012. Reduced severity and impact of Fusarium wilt on strawberry by manipulation of soil $\mathrm{pH}$, soil organic amendments and crop rotation. Eur. J. Plant Pathol. 134:619-629.

26. FAOSTAT. 2011. Food and Agriculture Organization of the United Nations. http://faostat.fao.org/site/567/default.aspx

27. Fravel, D., Olivain, C., and Alabouvette, C. 2003. Fusarium oxysporum and its biocontrol. New Phytol. 157:493-502.

28. Grogan, R. G., and Kimble, K. A. 1959. The association of Fusarium wilt with the asparagus decline and replant problem in California. Phytopathology 49:122-125.

29. Hamel, C., Vujanovic, V., Jeannotte, R., Nakano-Hylander, A., and StArnaud, M. 2005. Negative feedback on a perennial crop: Fusarium crown and root rot of asparagus is related to changes in soil microbial community structure. Plant Soil 268:75-87.

30. Hamel, C., Vujanovic, V., Nakano-Hylander, A., Jeannotte, R., and StArnaud, M. 2005. Factors associated with Fusarium crown and root rot of asparagus outbreaks in Quebec. Phytopathology 95:867-873.

31. Klein, E., Katan, J., and Gamliel, A. 2011. Soil suppressiveness to Fusarium disease following organic amendments and solarization. Plant Dis. 95:1116-1123.

32. Lacy, M. L. 1979. Effects of chemicals on stand establishment and yields of asparagus. Plant Dis. Rep. 63:612-616.

33. Lazarovits, G. 2001. Management of soil-borne plant pathogens with organic soil amendments: a disease control strategy salvaged from the past. Can. J. Plant Pathol. 23:1-7.

34. Leslie J. F., and Summerell B. A. 2006. The Fusarium Laboratory Manual. Blackwell Publishing Professional, Ames, IA.

35. Litterick, A. M., Harrier, L., Wallace, P., Watson, C. A., and Wood, M. 2004. The role of uncomposted materials, composts, manures, and compost extracts in reducing pest and disease incidence and severity in sustainable temperate agricultural and horticultural crop production: A review. Crit. Rev. Plant Sci. 23:453-479.

36. Martínez, M. A., Martínez, M. C., Bielza, P., Tello, J., and Lacasa, A. 2011. Effect of biofumigation with manure amendments and repeated biosolarization on Fusarium densities in pepper crops. J. Ind. Microbiol. Biotechnol. 38:3-11.

37. Melero-Vara, J. M., López-Herrera, C. J., Prados-Ligero, A. M., VelaDelgado, M. D., Navas-Becerra, J. A., and Basallote-Ureba, M. J. 2011. Effects of soil amendment with poultry manure on carnation Fusarium wilt in greenhouses in southwest Spain. Crop Prot. 30:970-976.
38. Morrison, W. R., III, Tuell, J. K., Hausbeck, M. K., and Szendrei, Z. 2011. Constraints on asparagus production: The association of Ophiomyia simplex (Diptera: Agromyzidae) and Fusarium spp. Crop Sci. 51:1414-1423.

39. Mulè, G., Susca, A., Stea, G., and Moretti, A. 2004. Specific detection of the toxigenic species Fusarium proliferatum and $F$. oxysporum from asparagus plants using primers based on calmodulin gene sequences. FEMS Microbiol. Lett. 230:235-240.

40. Nahiyan, A. S. M., Boyer, L. R., Jeffries, P., and Matsubara, Y. 2011. PCR-SSCP analysis of Fusarium diversity in asparagus decline in Japan. Eur. J. Plant Pathol. 130:197-203.

41. Ngouajio, M., and Counts, J. W. 2012. Effect of soil amendment on soil microbial activity and asparagus yield under a replant situation. Acta Hortic. 950:65-71.

42. Nitschke, E., Nihlgard, M., and Varrelmann, M. 2009. Differentiation of eleven Fusarium spp. isolated from sugar beet, applying restriction fragment analysis of polymerase chain reaction-amplified translation elongation factor $1 \alpha$ gene fragment. Phytopathology 99:921-929.

43. Noble, R., and Coventry, E. 2005. Suppression of soil-borne plant diseases with composts: a review. Biocontrol Sci. Technol. 15:3-20.

44. Ntougias, S., Papadopoulou, K. K., Zervakis, G. I., Kavroulakis, N., and Ehaliotis, C. 2008. Suppression of soil-borne pathogens of tomato by composts derived from agro-industrial wastes abundant in Mediterranean regions. Biol. Fertil. Soils 44:1081-1090.

45. Reid, T. C., Hausbeck, M. K., and Kizilkaya, K. 2002. Use of fungicides and biological control in the suppression of Fusarium crown and root rot of asparagus under greenhouse and growth chamber conditions. Plant Dis. 86:493-498.

46. Rozen, S., and Skaletsky, H. 2000. Primer3 on the WWW for general users and for biologist programmers. Methods Mol. Biol. 132:365-386.

47. Schreuder, W., Lamprecht, S. C., Marasas W. F. O, and Calitz, F. J. 1995. Pathogenicity of three Fusarium species associated with asparagus decline in South Africa. Plant Dis. 79:177-181.

48. Stephens, C. T., and Elmer, W. H. 1988. An in vitro assay to evaluate sources of resistance in Asparagus spp. to Fusarium crown and root rot. Plant Dis. 72:334-337.

49. Tenuta, M., and Lazarovits, G. 2002. Ammonia and nitrous acid from nitrogenous amendments kill the microsclerotia of Verticillium dahliae. Phytopathology 92:255-264.

50. Tsao, P. H., and Oster, J. J. 1981. Relation of ammonia and nitrous acid to suppression of Phytophthora in soils amended with nitrogenous organic substances. Phytopathology 71:53-59.

51. Vitale, S., Santori, A., Wajnberg, E., Castagnone-Sereno, P., Luongo, L., and Belisario, A. 2011. Morphological and molecular analysis of $F u$ sarium lateritium, the cause of gray necrosis of hazelnut fruit in Italy. Phytopathology 101:679-686.

52. Von Bargen, S., Martinez, O., Schadock, I., Eisold, A. M., Gossmann, B., and Büttner, C. 2009. Genetic variability of phytopathogenic Fusarium proliferatum associated with crown rot in Asparagus officinalis. J. Phytopathol. 157:446-456.

53. Vujanovic, V., Hamel, C., Jabaji-Hare, S., and St-Arnaud, M. 2002. Development of a selective myclobutanil agar (MBA) medium for the isolation of Fusarium species from asparagus fields. Can. J. Microbiol. 48:841-847.

54. Vujanovic, V., Hamel, C., Yergeau, E., and St-Arnaud, M. 2006. Biodiversity and biogeography of Fusarium species from Northeastern North American asparagus fields based on microbiological and molecular approaches. Microbiol. Ecol. 51:242-255.

55. White, T. J., Bruns, T., Lee, S., and Taylor, J. W. 1990. Amplification and direct sequencing of fungal ribosomal RNA genes for phylogenetics. Pages 315-322 in: PCR Protocols: A Guide to Methods and Applications. M. A. Innis, D. H. Gelfand, J. J. Sninsky, and T. T. White, eds. Academic Press Inc., New York.

56. Williams, K. J, Dennis, J. I., Smyl, C., and Wallwork, H. 2002. The application of species-specific assays based on the polymerase chain reaction to analyze Fusarium crown rot of durum wheat. Australas. Plant Pathol. 31:119-129.

57. Wong, J. Y., and Jeffries, P. 2006. Diversity of pathogenic Fusarium populations associated with asparagus roots in decline soils in Spain and the UK. Plant Pathol. 55:331-342.

58. Yergeau, E., Filion, M., Vujanovic, V., and St-Arnaud, M. 2005. A PCRdenaturing gradient gel electrophoresis approach to assess Fusarium diversity in asparagus. J. Microbiol. Methods 60:143-154.

59. Yergeau, E., Labour, K., Hamel, C., Vujanovic, V., Nakano-Hylander, A., Jeannotte, R., and St-Arnaud, M. 2010. Patterns of Fusarium community structure and abundance in relation to spatial, abiotic and biotic factors in soil. FEMS Microbiol. Ecol. 71:34-42.

60. Yergeau, E., Sommerville, D. W., Maheux, E., Vujanovic, V., Hamel, C., Whalen, J. K., and St-Arnaud, M. 2006. Relationships between Fusarium population structure, soil nutrient status and disease incidence in fieldgrown asparagus. FEMS Microbiol. Ecol. 58:394-403. 